\title{
Politics of place/space: The spatial dynamics of the Kurdish and Zapatista movements
}

\section{Zeynep Gambetti}

\begin{abstract}
This paper explores two examples of collective action, the Zapatista movement in Chiapas, Mexico, and the Kurdish movement in Turkey, by focusing on how these movements constructed two particular places, Diyarbakır and Chiapas, after the armed conflict subsided. My first aim is to show how this place-making has affected the discourses and practices of these movements. I argue that place-making is not only about locality or physical setting, but also about constructing a movement and a form of struggle in its own right. My second aim is to discuss the broad outlines of what may be called the "appropriation of space." This refers not only to the spaces of visibility and solidarity opened up by a movement, but also to its chances of acquiring significance within local, national or global spaces of power. I look at how the Kurdish movement has had an impact on democracy in Turkey and compare it with the Zaparista movement's local and transnational effects. I do so by relating physical and metaphorical notions of space to several concepts generated by social movement literature. As such, this study intends to contribute to spatial understandings of collective action. It is also likely to indicate various pitfalls and obstacles for emancipatory social movements in the present neoliberal era.
\end{abstract}

Zeynep Gambetti, Boğaziçi University, Department of Political Science and International Relations, Istan. bul, Turkey, gambetti@boun.edu.tr.

Author's Note: This paper is the product of fieldwork conducted at various times from 2003 to the present in Diyarbakır and Chiapas through consecutive funding obtained from the Boğaziçi University Scientific Research Fund (2003-2005 and 2007-present). Various methods were used during fieldwork, including semi-structured interviews and participant observation. A draft of this paper was presented at the Ninth Mediterranean Research Meeting organized by the Mediterranean Program of the Robert Schuman Centre for Advanced Studies at the European University Institute, in Florence, Italy, 12-15 March 2008. I would like to thank Seteney Shami of the SSRC for making this workshop possible, Srirupa Roy for co-directing it, and Banu Bargu, Gerardo Renique, Polly Pallister-Wilkins, Deniz Yükseker and two anonymous reviewers for valuable comments that helped revise this text. 
Keywords: politics of place, spatiality, social movements, Zapatista movement, Kurdish movement, Diyarbakır, Chiapas

This paper is an attempt to explore two cases of collective action that have rarely been discussed in connection with each other: the Zapatista movement in Chiapas, Mexico, and the Kurdish movement in Turkey. ${ }^{1}$ The geographical, cultural and political contexts within which the two movements have emerged are so far removed from each other that any attempt to compare becomes a complicated feat. My concern here is neither to demonstrate the validity or usefulness of the literature on social movements in studying seemingly disparate movements, nor to put to test various analytical tools designed for comparative politics. $\mathrm{M}_{Y}$ concern, rather, is to contribute to the recent literature on the spatiality of social movements. For I will argue that the movements in question, in spite of their dissimilarities, entertain a specific relation to place and space. They thereby constitute promising venues through which to enhance scholarly reflection on the politics of place/space. Far from pretending to be an exhaustive study of the two movements, then, this paper focuses on how two particular places, Diyarbakar and Chiapas, were constructed by movements that were armed at the beginning, but consecutively turned "civil" or "social," by opening a space for themselves within the respective dominant political frameworks.

One aim of this paper is to see how place-making has affected the discourses and practices of these movements. I suggest that place-making is not only about constructing a physical location that will "host" the movement, or about investing a place with symbolic meaning; it is also (and perhaps more significantly) about generating a resource that builds up the mobilizing capacities of a movement. The cases in question point to the significance of place as a political opportunity structure that (re) constructs social movements. Spatial transgressions, furthermore, are forms of resistance in themselves. Place-making is part of the struggle (and undeclared aims) of a movement. As such, it may well be indispensable as far as the declared causes for mobilization are concerned.

A second aim of the paper is to discuss the broad outlines of what I call the "appropriation of space," which refers to the potential of social movements to alter power structures in a given polity, which is itself not necessarily confined to the territory of a nation-state. Acknowledging

1. One notable exception is Peasant Rebellion in the Age of Clobalization: The Zapatistas of Mexico and the Kurds of Turkey, a Ph.D. thesis in sociology that is currently being written by Mehmet Küçüközer at the City University of New York Craduate Center. 
that spatial and social justice are closely related, I argue that the diffusion of a movement beyond a specific locality (by "jumping scales"), the extension of networks, and innovations made in movement repertoires are vital for the sustainability of grassroots collective action in the era of neoliberalism. I use "space" mostly in the metaphorical-associative sense of forging open a space of recognition through which a social movement is capable of triggering durable effects on social and political structures. As such, the appropriation of space can indeed be considered as the cause (and not necessarily the outcome) of the "cognitive liberation" that McAdam takes to be a precondition of mobilization. ${ }^{2}$

This is the main axis forming the ground of comparison for my geographically distinct cases. In this paper, I will first engage with some of the relevant theoretical literature on social movements, space and neoliberal transformation. Then, I will present a brief history of the two armed movements that evolved gradually into social ones: the Zapatista movement initiated by the Zapatista National Liberation Army (EZLN) in Mexico, and the Kurdish movement that emerged from the Workers' Party of Kurdistan (PKK) in Turkey. Consequently, I will focus on how two particular places, Diyarbakır and Chiapas, were constructed by these movements. The aim here is to show how place-making has affected the discourses and practices of the two movements. Finally, in the fourth part, I will sketch a broad outline of what I call the "appropriation of space" by the Zapatistas and the Kurds. Without pretending to be either exhaustive or conclusive, I will discuss the potential of these movements to democratize power structures in their respective countries. ${ }^{3}$ The latter are undergoing significant changes in their economic and political structures, owing to what can be called the "neoliberal turn." My discussion of space considers this transformation to be one of the most significant challenges that social movements in the globalizing world are facing.

\section{The spatiality of movements in the neoliberal era}

Replacing (or at times supplementing and transforming) previous accounts of collective protests, revolts and revolutions based on the ideas

2 Doug McAdam, Political Process and the Development of Black Insurgency, 1930-1970, $2^{\text {nd }}$ ed. (Chicago: University of Chicago Press, 1999), 48-51.

3 Needless to say, the perspective I am proposing is from an outside point of view: I neither claim to have an insider's grasp of the intricacies of the movements under consideration, nor an anthropologists' insight into daily life processes. I might therefore be doing injustice to the sufferings that the two armed processes express or cause. My normative stance sterns from my particular position within the field in which these social movements have emerged, a field to which they respond or which they willingly or unwillingly transform. 
of deprivation and grievance, social scientists have explored several different paths in the study of social movements over the past thirty years. In the US, scholars espousing the resource mobilization theory contend that movement mobilization needs to be accounted for by the availability and employment of such resources as organizational means, funds, elite and expert involvement, network formation, and incentives for recruitment and participation. ${ }^{4}$ Another line of research is based on what has been called political process theory, which argues that broader political and cultural structures shape the capacity of movements to mobilize and achieve goals. ${ }^{5}$ The lacunae in each of these theories have spurred more synthetic approaches in the past decade. ${ }^{6}$ One point of convergence significant for the purposes of this paper is between the individual and societal dynamics of movement formation. According to Tarrow, for instance, political opportunity structures are "consistent-but not necessarily formal, permanent or national-dimensions of the political struggle that encourage people to engage in contentious politics," while political constraints are "factors-like repression, but also like authorities' capacity to present a solid front to insurgents-that discourage contention." The focus has shifted from this narrowly political approach towards one that incorporates individual mobilizing structures and more general cultural framing. Mobilizing structures or social networks are ties of face-to-face interaction, personal and group allegiances, organizational resources, or spaces of assembly, as well as inter-organizational links in which individual members of a movement are "embedded." As such, networks and opportunities are not mutually exclusive, although there is considerable ambiguity as to whether networks exist prior to the emergence of a movement or are constituted by and through it. ${ }^{8}$

The more European strand of social movement research has focused less on the mechanisms of mobilization and organization of particular

4 James McCarthy and Mayer N. Zald, "Resource Mobilization and Social Movements," American Journal of Sociology 82, no. 6 (1977); J. Craig Jenkins, "Resource Mobilization Theory and the Study of Social Movements," Annual Review of Sociology, no. 9 (1983); A. D. Morris and C. M. Mueller, eds., Frontiers in Social Movement Theory (New Haven and London: Yale University Press, 1992).

5 Charles Tilly, From Mobilization to Revolution (Reading: Addison-Wesley, 1978); McAdam, Black Insur. gency; Sidney Tarrow, Democracy and Disorder (Oxford: Oxford University Press, 1989).

6 Doug McAdam, John McCarthy, and Mayer N. Zald, "Introduction: Opportunities, Mobilizing Structures, and Framing Processes - Toward a Synthetic, Comparative Perspective on Social Movements," in Comparative Perspectives on Social Movements: Political Opportunities, Mobilizing Structures and Cultural Framings, eds. Doug McAdam, John McCarthy, and Mayer N. Zald (Cambridge: Cambridge University Press, 1996).

7 Sidney Tarrow, Power in Movement (Cambridge: Cambridge University Press, 1998), 20.

8 Jeff Goodwin and James M. Jasper, "Caught in a Winding, Snarling Vine," in Rethinking Social Movements: Structure, Meaning, and Emotion, ed. Jeff Goodwin and James M. Jasper (Lanham: Rowman and Littlefield Publishers, 2004), 17-18. 
movements than on structural changes in Western societies. It is being claimed that, instead of the "old" movements' engagement with the political or with labor and economic issues, "new" movements in complex, industrialized societies centralize around changes in lifestyle, collective identities, and cultural demands. ${ }^{9}$ They deal with "cultural and especially ethical problems, because the system which is challenged controls not only 'means of production' but the production of symbolic goods, that is, of information and images, of culture itself." ${ }^{\prime 10}$

New social movement theories were actually "part of wider efforts to theorize periodizations of collective action through examining 'origins,' 'waves,' 'cycles,' and 'protest repertoires."' ${ }^{11}$ Tilly's notion of repertoire, for instance, refers to shared understandings, memories and culturally determined "agreements" that arise not only from particular historicalstructural dynamics, but also, and more significantly, from social movement activity itself. Repertoire "identifies a limited set of routines that are learned, shared and acted out through a relatively deliberate process of choice,"12 although a repertoire of actions "resembles not individual consciousness but a language." ${ }^{13}$ Repertoires constrain behavior and choice, but are also depositories of practical know-how. They are constituted through innovation and/or repetition within the lifetime of a social movement. As such, earlier forms of struggle and protest open up spaces for subsequent cycles. Thus, political process theory has come to conceptualize opportunity, not only as an analytical tool to understand the emergence of protest movements, but also the subsequent transformations they undergo during their lifetime. ${ }^{14}$

The notions of embeddedness and context-dependency that are explicitly or implicitly present in the above formulations would call for conceptualizing the spatiality of social movements, but place and space have long been relegated to a secondary status by social movement theorists. As Tarrow points out,

9 Jürgen Habermas, "New Social Movements," Telos, no. 49 (1981); The Theory of Communicative Action, Vol. 2, System and Lifeworld: A Critique of Functionalist Reason (Cambridge: Polity Press, 1987); Alberto Melucci, "The Symbolic Challenge of Contemporary Movements," Social Research 52, no. 4 (1985); Klaus Eder, "The New Social Movements: Moral Crusades, Political Pressure Groups, or Social Movements," Social Research 52, no. 4 (1985).

10 Alain Touraine, "An Introduction to the Study of Social Movements," Social Research 52, no. 4 (1985).

11 Marc Edelman, "Social Movements: Changing Paradigms and Forms of Politics," Annual Review of Anthropology, no. 30 (2001): 294.

12 Charles Tilly, "Contentious Repertoires in Great Britain, 1758-1834," in Repertoires and Cycles of Contention, ed. M. Traugott (Durham: Duke University Press, 1995), 26.

13 Ibid., 30 .

14 See McAdam, Black Insurgency; Debra Friedman and Doug McAdam, "Collective Identity and Activism: Networks, Choices, and the Life of a Social Movement," in Frontiers in Social Movement Theory. 
[n]umerous scholars have focused on contention across space, and have involved different territorial units. But accounts of space are often underspecified, ignoring the fact that space structures both contention and repression; that contention is often about space; and that public spaces often structure the way contention unfolds and is remembered. ${ }^{15}$

Indeed, most of the literature "has treated space as an assumed and unproblematized background, not as a constituent aspect of contentious politics that must be conceptualized explicitly and probed systematically."16 Byron Miller has lamented that time has been prioritized in studying social movements, but that the same degree of attention is not directed to "spaces" or "places" of protest: "For the most part, space is viewed as little more than a container for aspatial social processes; there is no recognition that the spatial constitution of mobilization processes affects their operation." 17 The dualism between the "social" and the "spatial" has been maintained in studies that treat space as merely another dependent variable that needs to be taken into account. ${ }^{18}$ Although the conceptualizing of collective action frames has moved the emphasis of social movement research from "objective" resource availability to the more "discursive" notion of "framing," few researchers "address the place-based framing of movements."19

Be that as it may, nobody would contest the idea that spatiality makes a critical difference in the sustainability of collective action, or in determining the outcome of contentious politics. Lefebvre's path-breaking 1974 study has:explored space as a social product that affects practices, thoughts and possibilities of action. ${ }^{20}$ Studies on the Paris insurrections of 1848 and 1870-71 have shown that "a place-sensitive perspective on collective behavior" was highly developed in the nineteenth century, and

15 Sidney Tarrow, "Silence and Voice in the Study of Contentious Politics: Introduction," in Silence and Voice in the Study of Contentious Politics, eds. Ronald Aminzade et al. (Cambridge: Cambridge Univer. sity Press, 2001), 11.

16 William Sewell, "Space in Contentious Politics," in Silence and Voice in the Study of Contentious Politics, eds. Ronald Aminzade et al. (Cambridge: Cambridge University Press, 2001), 51-52.

17 Byron Miller, Geography and Social Movements (Minnesota: University of Minnesota Press, 2000), 6. Miller's first chapter, "Missing Ceography: Social Movements on the Head of a Pin?," co-written with Deborah C. Martin, provides an excellent overview over efforts to incorporate space and place into social movement studies.

18 Ibid., 4-5.

19 Robert D. Wilton and Cynthia Cranford, "Toward an Understanding of the Spatiality of Social Move. ments: Labor Organizing at a Private University in Los Angeles," Social Problems 49, no. 3 (2002): 378.

20 Henri Lefebvre, The Production of Space (Oxford, UK and Cambridge, Mass.: Blackwell, 1991). The book was first published in French in 1974. 
that the urban transformation of Paris undertaken by Haussmann between the two insurrections was instrumental in sealing the fate of the Paris Commune. ${ }^{21}$ The works of Neil Smith, David Harvey and Edward Soja to a large extent center on the complex relationship between space and social practice. ${ }^{22}$ The 1989 Tiananmen uprising in China, the Madres de Plaza de Mayo movement, and the 1968 student revolts in California and Paris cannot be conceptualized without reference to the particular places in which they emerged. In a study that takes space as a central element, for instance, Wilton and Cranford have shown how struggles over space are central to a social movement's capacity to challenge local patterns of resource allocation and address broader issues of social justice. In fact, "the occupation and appropriation of space can function as political strategies in efforts to disrupt the balance of power maintained by dominant classes." 23

This paper subscribes to the concern animating Bosco's research into the spatiality and relationality of the Madres de Plaza de Mayo-namely, that although

we know that different social movement processes (for example, recruitment, mobilization, or continuity) are mediated and negotiated through networks with different spatialities, it remains unclear whether and how the spatial dimensions of different relations in a network may actually affect the development of such social movement processes. ${ }^{24}$

It is especially of interest to look into the dynamics of "how spaciality is related to the constraining and enabling dimensions of relationships in a network." 25

For a long time, space was seen as either the recipient or the outcome of social processes. Poletta, for instance, has insisted that the concept of "free spaces" (such as the Black churches in the case of the civil rights movement) be abandoned in favor of the underlying associative ties

Thomas F. Gieryn, "A Space for Place in Sociology," Annual Review of Sociology, no. 26 (2000): 478.

See Neil Smith, Uneven Development: Nature, Capital, and the Production of Scale, $3^{\text {rd }}$ ed. (Athens: University of Georgia Press, 2008); Edward Soja, Postmodern Geographies: The Reassertion of Space in Critical Social Theory (London: Verso, 1989); Postmetropolis: Critical Studies of Cities and Regions (Oxford: Blackweil, 200o) and; David Harvey, The Condition of Postmodernity (Oxford: Basil Blackwell, 1989), and Spaces of Hope (Berkeley: University of California Press, 2000), among others.

Wilton and Cranford, "The Spatiality of Social Movements," 377.

Fernado 1. Bosco, "Place, Space, Networks and the Sustainability of Collective Action: The Madres de Plaza de Mayo," Global Networks 1, no. 4 (2001): 310.

Ibid. 
for which it stands as a metaphor. ${ }^{26}$ It is the character of associational ties that are established or reinforced in physical gathering spaces, she contends. Therefore, the social must be prioritized over the spatial. Although such metaphorical or relational approaches to space are valuable for the purposes of this research, as I will argue shortly, physical and geographical space is also indispensable for the comprehension of social movements. As Massey has demonstrated, "there are no purely spatial processes, neither are there any non-spatial social processes." 27 The active production of space by social processes and movements needs to be taken into consideration, just as much as the active production of movements by physical and geographical space.

In this study, I will use "place" to refer to a geographic location and to material forms constructed by everyday social practices in that location. ${ }^{28}$ These are invested with meaning and value, which accounts for their being identified as places:

[Place] stabilizes and gives durability to social structural categories, differences and hierarchies; arranges patterns of face-to-face interaction that constitute network-formation and collective action; embodies and secures otherwise intangible cultural norms, identities, memories - and values [...] These consequences result uniquely (but incompletely) from material forms assembled at a particular spot, in part via the meanings that people invest in a place. ${ }^{29}$

Place, then, is likely to have a significant impact on the structure of the movement itself. A social movement is not only constituted by the motivations and/or limitations of its actors, but also by the ways in which it interacts with and is marked by place.

Most significantly, the Madres example has prompted Bosco to evoke bell hooks' concept of "homeplace" of resistance in order to argue that

place-based collective rituals-the rootedness and frequent practice of activities in particular places of symbolic importance for a group-

26 Francesca Polletta, "Free Spaces' in Collective Action," Theory and Society 28, no. 1 (1999).

27 Doreen Massey, Spatial Divisions of Labor: Social Structures and the Geography of Production, revised $2^{\text {nd }}$ ed. (New York: Routledge, 1995), 51.

28 This definition is more or less in line with what Arturo Escobar has in mind when he says "Culture sits in places," i.e., that "place refers to the experience of, and from, a particular location with some sense of boundaries, grounds, and links to everyday practices [...] all of these are constructed, and not only by place-based processes." ("Culture Sits in Places: Reflections on Clobalism and Subaltern Strategies of Localization," Political Ceography 20, no. 2 (2001): 152.)

29 Gieryn, "A Space for Place in Sociology," 464-465. 
play a role in the sustainability of activism and of a shared collective identity even among members of geographically extensive networks of activists. ${ }^{30}$

This idea, I will argue, sheds considerable light on the cases of Diyarbakir and Chiapas and permits interesting comparisons between the two.

"Space" is an analytical concept that I distinguish from place, despite opposition by geographers. In the way I use it, space is related to the broader field in which the social movement operates. I use it in the metaphorical sense, in that space "carves out 'room to move,' the space in which to be fecund, dialectical, life-giving." 31 Appropriating space means gaining a foothold within a given social imaginary. It is a space of visibility, in Melucci's sense, "an intermediate public space, whose function is not to institutionalize the movements nor to transform them into parties, but to make society hear their messages and translate these messages into political decision making, while the movements maintain their autonomy." ${ }^{12}$ Going even further, I use the term to refer to the capacity of a social or political movement to become a conditioning factor-that is, to leave symbolic or institutional traces on social processes beyond its particular place of action.

As such, Nelson's concept of "sedimentation" is useful for my conceptualization. Sedimentation processes refer to the ways in which the discourses and pracrices initiated by a movement continue to institutionalize, even after the latter has worn out. As defined by Nelson,

[sedimentation] refers to the complex processes through which discourses (including 'identities', political vocabularies, and practices) deployed in moments of collective organization and protest become translated and socially embedded by a variety of actors, not only over time but through disparate social and political arenas." 33

This also introduces a temporal dimension into the study of spatiality, a dimension that may surpass the life-span of the movement itself. The movement is thereby de-centered. The ripple effects that it creates among its declared supporters and among unexpected circles (includ-

30 Bosco, "Madres de Plaza de Mayo," 317.

31 Neil Smith, "Contours of a Spatialized Politics: Homeless Vehicles and the Production of Geographical Scale," Social Text, no. 33 (1992): 64.

32 Melucci, "The Symbolic Challenge," 815.

33 Lise Nelson, "Decentering the Movement: Collective Action, Place, and the 'Sedimentation' of Radical Political Discourses," Environment and Planning D: Society and Space 21, no. 5 (2003): 559. 
ing hostile groups) get considerable attention when analyzing the overall transformative influence of the movement. To this end, it is necessary to look into how collective action prompted by a movement affects the lives and practices of communities directly or indirectly related to the movement in various ways.

I have explored elsewhere the discomforting idea that conflict may render a movement, a cause, or an identity visible by forcefully inserting it into the dominant public space. ${ }^{34}$ For without the appearance of conflicts and identities, differences, commonalities and power structures to heterogeneous publics, neither the designation of a given problem as a common problem that prompts action, nor proper "commun-ication" (rendering common) is possible. Publicity is a necessary (though not sufficient) condition for creating a mobilizing bond that alters or reshapes power structures. Put differently, spatial transgressions can be considered disruptions of the taken-for-granted organization of social (and political) space. ${ }^{35}$ Likewise, "jumping scales" 36 is not only one of the ways in which a social movement expands and gains staying power, but also a transgression or modification by the movement of the set of political alternatives available to the polity in which it emerges.

However, something should be said about the temporal horizon in which these two movements maintain their existence. As Harvey has so convincingly pointed out, in most parts of the world spaces and places are increasingly shaped by the dynamics of neoliberalism. ${ }^{37}$ Loss of place as "mobility," "displacement," and "deterritorialization" become the paradigmatic figures of our times. ${ }^{38}$ The problem is aggravared by how global neoliberalism disturbs spaces of possible interest aggregation, other than those serving the new regime of capital accumulation. It is certainly paradoxical that the proliferation of what is called identity politics coincides with the forceful alteration of modes of production and accumulation. As Harvey has pointed out, acceleration in turnover times of capital, the turn to the provision of ephemeral services, and the

34 Zeynep Gambetti, "The Conflictual (Trans) formation of the Public Sphere in Urban Space: The Case of Diyarbakır," New Perspectives on Turkey, no. 32 (2005); and "Conflict, 'commun-ication' and the Role of Collective Action in the Formation of Public Spheres," in Publics, Politics and Participation: Locating the Public Sphere in the Middle East and North Africa, ed. Seteney Shami (New York: Columbia/SSRC Books, 2010 [forthcomingl).

35 See Wilton and Cranford, "The Spatiality of Social Movements," 377.

36 Neil Smith, in "Contours of a Spatialized Politics," defines this as such: dissolving "spatial boundar. ies that are largely imposed from above and that contain rather than facilitate [the] production and reproduction of everyday life," 60 . 
process of flexible accumulation have led to a "rapid write-off of traditional and historically acquired values." ${ }^{39}$ In fact, the fragmentation of formerly unified (and thereby normalizing) social struggles is partially responsible for the growing inability of alternative groups to occupy any ground in both the physical and the relational sense. In a world connected through hegemonic discourses that tend to erase the conditions that make it possible to sustain democratic grassroots activity, the capacity of a social movement to hold enough ground in order to become a conditioning factor is a fundamental issue that needs to be addressed. Seizing or opening up a space of existence bestows a tangible reality on a political community, stabilizes the power generated by collective action, and institutes the conditions of remembrance. ${ }^{40}$ It was Lefebvre's insight that any 'social existence' aspiring or claiming to be 'real,' but failing to produce its own space, would be a strange entity, a very peculiar kind of abstraction unable to escape from the ideological or even the 'cultural' realm." ${ }^{41}$

Seen in this manner, place-making and the appropriation of space both provide entry points from which to link movements in different geographies. By combining along these lines insights obtained from research on space and on social movements, I will assess my two cases, without singling out a particular paradigm or conceptual framework, but instead attempting to show the complexity and interrelatedness of such elements as opportunity structure, repertoire, network, place, space, and scale.

\section{Two geographically distant cases of forceful insertion}

Both the PKK and the EZLN are armed guerilla groups that have set off a variety of pacific forces no longer under their direct control. What is of interest for the purposes of this paper is how a social movement has emerged from an armed one.

Although the common tendency in Kurdish studies is to focus on the $\mathrm{PKK}$ as the mastermind and main impetus behind the Kurdish movement in Turkey, I find this approach lacking, for at least three important reasons: (1) The long and tortuous path that first brought legalization in 1990 and then, from 1999 onwards, a degree of legitimacy to Kurdish political parties inevitably drove the latter into a course that no longer

39 Harvey, The Condition of Postmodernity, 290.

40 This is where the distinction between being in the world and being of the world becomes most evident. Cf. Jacques Taminiaux, La fille de Thrace et le penseur professionnel: Arendt et Heidegger (Paris: Payot, 1992), 162.

41 Lefebvre, The Production of Space, 53. 
fully coincides with that of the PKK. (2) Victories won by legal Kurdish parties in municipal elections in the southeastern provinces from 1999 onwards have initiated local discourses and practices that no longer fully overlap with the PKK's broader national/transnational concerns and claims. Thus, the political and social opportunity structures can be said to have changed for the Kurdish movement as a whole. (3) The bonds and alliances that Kurdish political leaders have formed over the past few years with Turkish intellectuals, artists, academics and activists are not spurred by the PKK; rather, they are attempts to disarm the PKK by bringing about the conditions necessary for peace and reconciliation. It can thus be argued that the Kurdish movement's network formation process is not necessarily the same as the PKK's.

As a guerilla force with a vindictive ideological agenda and a strong personality cult, the PKK has been ineffective in adapting itself to domestic and global changes during the span of its thirty-year existence. ${ }^{42}$ It has secured considerable grassroots support through indoctrination and/or cashing in on the various forms of repression and violence that the state as well as tribal life inflicts on Kurds, mainly in southeastern Turkey. Attempts to diversify and multiply the Kurdish movement through workers' unions, civic associations, cultural centers, visual and print media and through a series of political parties formed from 1990 onwards (HEP, ÖZDEP, DEP, HADEP, DEHAP and DTP) have often stumbled over the PKK's hard-line strategies as well as the Turkish establishment's intolerance. Nevertheless, especially after the 1999 municipal victories, Kurdish parties were able to develop extensive relations with constituencies and civic organizations. Despite continuing pressures from both the PKK's central command and the Turkish establishment, the latter came to have a life of their own, although they do at times seem to lead a double life. In my view, what has turned a militaristic stance into a social movement are the networks constituted around legal Kurdish groups.

The PKK started out as a handful of determined Marxists gathering around the charismatic figure of Abdullah Öcalan in the late 1970s. Embracing a Marxist-Leninist ideology and holding the conviction that an independent nation-state was the only way to put an end to the repression and denial of Kurdish identity in the Turkish Republic, it opted for violent tactics at the onset. After the party program was drawn in 1978 , the PKK's first attack was on a local depury and large landowner

42 This is apparently how Öcalan judged his own organization. See Ali Kemal Özcan, "The Vacillating PKK: Can It Be Resurrected?," Middle Eastern Studies 43, no. 1 (2007): 114-115. 
in Shanliurfa. The 1980 military coup in Turkey caused it to move to the Bekaa Valley in Lebanon in order to train and consolidate its structure. In 1984, a year after the military junta stepped back into the barracks, the PKK re-launched itself in Turkey by raiding two army outposts in the Southeast. The Turkish state retaliated by declaring a State of Emergency in eleven southeastern provinces in 1987, recruiting and arming Kurdish peasants to serve as village guards and sending thousands of well-equipped troops to the region, in order to conduct massive operations in mountain hide-outs as well as in, villages and ciries. This led to a gradual swelling of PKK ranks, as victims of the arbitrary treatment and brutal conduct of the village guards and rank-and-file army took to the mountains in reaction. By 1993, Öcalan was claiming that he had 30,000 guerillas under his command. ${ }^{43}$ This was also the period during which major popular uprisings and rioting called serbildans (the Kurdish word corresponding to the Palestinian intifada) took place in several cities. The Turkish army's scorched earth strategy was backfiring.

Meanwhile, the first legal Kurdish party, HEP, was formed in 1990. This was both a new turn and the beginning of the decline of the armed movement. Tactical mistakes by the HEP (such as taking the parliamentary oath in Kurdish) and the establishment's unswerving intent on using every means to crush the movement finally resulted in a military and political victory over the PKK. The reformist wing of the newly formed KONGRA-GEL (this was the PKK after having undergone a name change) avowed that

[the] number of guerrillas, which was 13,000 in 1993 , had fallen to 8,500 in 1998. In other words, the reduction was 40 per cent [...] The growth of the guerrilla had stopped; the percentage of recruitment was not enough to meet half of the losses. The political [serbildans] had been reduced to some events on specific annual days. ${ }^{44}$

The PKK fell into quasi total disarray upon the capture of Öcalan in 1999.45

The PKK did not allow for any Kurdish movement other than itself to emerge in Turkey in the post-1980 period. Groups or intellectuals who attempted to form an alternative organization were either silenced or killed. ${ }^{46}$ On the other hand, the Turkish establishment was so sus-

43 Ibid.: 108

44 Cited by Ozcan, "The Vacillating PKK," 120.

45 Chris Kutschera, "Disarray inside PKK," The Middle East, May 2000.

46 Kemal Burkay's Kurdistan Socialist Party was stifled by the PKK and soon eclipsed under the weight of 
picious of any affirmation of Kurdish identity that it likewise silenced or exterminated prominent figures. ${ }^{47}$ Between two ideologies that paradoxically mirrored one another, almost no space was left for nonantagonistic discourses. This can be grasped through the plight of the legal Kurdish parties in Turkey. HEP was formed by Kurdish deputies expelled from the ranks of the social democrat SHP. A year later, HEP and SHP entered into an electoral alliance which gave HEP the chance to overcome the 10-percent national electoral threshold and to place 22 deputies in parliament. ${ }^{48}$ But the establishment found endless reasons to ban the party. Through a name-change maneuver, HEP retained its deputies, by becoming first ÖZDEP and then DEP. But such pressures also led to the radicalization of the party. As Barkey has observed,

[w] hereas HEP was a Kurdish party in essence, it made an effort to appeal beyond the ethnic dimension and had symbolically selected a Turk as its first president. DEP, by contrast, following the failure of the 1993 PKK-initiated cease-fire, became increasingly more strident and willing to take chances with the establishment. ${ }^{49}$

Thus caught in the mirror effect between the two main protagonists of the Kurdish problem, the DEP was also banned and its leaders imprisoned or forced into exile.

It was only with the simultaneous retreat of the two antagonistic hegemonic forces (the PKK and the Turkish military) that an alternative space could finally be constructed. That space owed its existence to the capture of Öcalan in 1999 and the signing of the Helsinki Agreement between Turkey and the EU in the same year. Through the agreement, Ankara made a number of democratic commitments in view of full membership and conceded to be closely inspected by the EU in regard to its human rights record. This was indeed a significant change in the political opportunity structure available to the Kurdish movement in Turkey.

A similar occurrence can also be observed in Chiapas. The EZLN's war on the Mexican government coincided with the entry into force of the NAFTA agreement between Mexico, the US, and Canada. This was

HEP, DEP and HADEP. Şerafettin Elçi's Democratic Mass Party did not succeed in organizing itself, owing to its anti-PKK position. Cf. Henri J. Barkey, "The People's Democracy Party (HADEP): The Travails of a Legal Kurdish Party in Turkey," Journal of Muslim Minority Affairs 18, no. 1 (1998): 134.

47 As many as 92 members of the successive parties HEP-DEP.HADEP fell victim to mysterious killings. Ibid.: 135 .

48 Ibid.: 130.

49 Ibid. 
not planned from the outset; the date was chosen because the EZLN could not complete its military preparations earlier. ${ }^{50}$ But the coincidence proved to be rewarding since it obliged the Mexican government to agree to negotiate with the rebels only twelve days after the armed uprising. The government did not want to lose its marketing image with its northern neighbors. This is as much the reason why the Chiapas rebellion could rapidly enter a new phase to construct an alternative space. The question of whether the Clandestine Committee's energetic appeal to civil society in Mexico and elsewhere over the internet could have saved the EZLN from being crushed by the Mexican army's tanks and heavy weaponry, had there not been this critical moment during which the government was worrying about its image, is a question left unanswered. Likewise, then, the EZLN thrust itself into the public limelight at a time when political opportunity structures were changing.

- The EZLN was actually a branch of the FLN founded by radical Marxist students in the 1970s. When a small group of would-be guerillas decided to take residence in the Lacandón jungle to try to organize a rebellion there in 1984, they did not have the means-that is, the language, the population's confidence of the population, and so on-to begin to communicate with indigenous people. This part of the story of the EZLN is still understudied, despite its enormous significance. The same can be said of the PKK's story. How did the rebel groups make their first contacts? What discourses did they construct or employ to mobilize the local population? What barriers did they face during the mobilization process? For instance, the PKK had to moderate its discourse against religion in the 1990s, because of "the recognition of the defeat of the Marxist teachings in the region[,] the PKK had to rely on Islamic inspiration to get public support for its activities." ${ }^{11}$ Likewise, the EZLN had to readjust its Marxist and vanguard rhetoric. The guerillas first had to make themselves useful in the communities and only then could begin to mobilize them through a great deal of indoctrination. ${ }^{52}$

50 Nick Henck, Subcommander Marcos: The Man and the Mask (Durham and London: Duke University Press, 2007), esp. chapter 3.

51 Anonymous author, "The Case of the PKK: History, Ideology, Methodology, and Structure (1978-99)," Ankara Papers 9, no. 1 (2004): 31.

52 As a hierarchical organization that only accepted a single philosophy, the PKK relied more heavily on ideological education and military training. See Ozcan, "The Vacillating PKK," esp. 31-32. But to attribute the organization's relatively significant success in augmenting its ranks to its supposed tactics of "terrorizing the people into supporting the organization" ("The Case of the PKK," 36) would be a biased assessment. No study has been undertaken on why ordinary peasants joined the PKK's ranks. Pending such evidence, however, it is not possible to make an off-hand judgment. 
The Zapatista war lasted a very brief twelve days. One of the reasons why the PKK's war had to last a full fifteen years before any alternative space could be constructed is that both the Turkish economy and Ankara's international relations could sustain themselves against all odds. ${ }^{53}$ In 1984, when the war started, Turkey was isolated from the international community because of its military coup. The military junta cleared the way for a rapid transition to a liberal market economy. The economy consequently boomed and attained GDP growth as high as an eightpercent annually. Such a dynamic market became more and more attractive to foreign investors who, despite the ongoing war in the southeast (or maybe even because of it), began investing heavily in Turkey. Government bonds sold in international markets were also a source of attraction to investors. Briefly put, despite verbal pressure from the European Union as to its human rights record, neither business elites nor politicians felt the need to modify the hard-line approach in dealing with the Kurdish question. With the exception of some efforts attributed to the late President Turgut Özal (1927-1993), no high-ranking Turkish politician regarded negotiating with the $\mathrm{PKK}$ a viable option to end the war.

In contrast, the Mexican government immediately had to negotiate with the EZLN. The prospect of endangering the benefits expected to accrue from NACLA was too risky. Mexican and international civil society also constituted a factor to be dealt with at the onset. The political opportunities available to the EZLN were thus much more favorable.

A similarity must be noted, however: Both armed uprisings forced the plight of the Kurds and that of the indigenous people in Chiapas into the limelight in a dramatic fashion. The spokesperson of the EZLN, Subcommandante Marcos, succinctly describes the indigenous uprising as a form of "dying in order to live." 54 Likewise, the prominent Turkish journalist Hasan Cemal admits:

In Turkey, neither journalists nor the press fulfilled their duties with respect to the Kurdish or the Southeastern problem. The number of those who did remained low. I admit it. As a graduate of political science, I did not know what the Kurdish problem was. It was only when the PKK entered the political scene that I started to learn. ${ }^{55}$

53 Another reason is, of course, the fact that the PKK has resorted to terrorist tactics against civilians, whereas the EZLN has not.

54 Subcommandante Marcos, "Dying in Order to Live," in Our Word is Our Weapon. Selected Writings, ed. 1. Poncé de Leon (New York: Seven Stories Press, 2002), 17.

55 Hasan Cemal, "Basın General Emri Dinlememeli (Interview with Neşe Düzel)," Radikal, 26 May 
This avowal, along with Marcos's tragic statement, tells us a lot about how power structures operated in both countries prior to the uprisings. The Kurds were not "relegated to oblivion," like the indigenous populations in Mexico, but they were constantly considered suspicious elements that could only stop being a threat to the unity of the nation by being assimilated. ${ }^{56}$ The indigenous in Mexico, meanwhile, were treated as quasi-serfs, even though Mexican national identity used Maya symbols to re-invent the mythical ancestral roots of the Mexican republic.

What needs to be noted here is that the armed uprisings in both countries served to force open a space of recognition. In Turkey, the effect was more gradual, since the PKK's initial operations were discursively identified by the establishment as isolated instances of terrorism by a handful of fanatic separatists. It was only when a state of emergency was declared in the Southeast in 1987 and the uprising took a massive turn with the serbildans in 1990 that the term "the Kurdish problem" entered into circulation in the public sphere. This finally gave the Kurdish uprising an "event character," an attribute that the 1994 Zapatista takeover of four cities in Chiapas immediately acquired.

The EZLN imposed itself on the Mexican government in a similar vein. The willingly spectacular seizure of a place, the city of San Cristobal de las Casas, and the subsequent usage of the internet to convey the Zapatista message to national and international publics constitured a rupture that had to be faced by state officials. ${ }^{57}$ Neither the dominant media, nor political rhetoric could employ customary tactics to render the uprisings invisible, insignificant or radically evil.

Another similarity must be noted. The event character of the uprisings had paradoxical consequences: (1) both uprisings were able to attain a huge amount of publicity, arousing the attention of the political establishment, the media, civil society and scholars; and (2) in both cases, the preparatory phase that came before the event and the reconstruction phase that came after it were relegated to secondary status because of the spectacle itself. In other words, the event can be said to have overshadowed the less spectacular aspects of the movement.

This is evident especially in Turkey where scholars pay scant attention to the current Kurdish party DTP, or to organizations that prioritize the Kurdish issue in their internal regulations or activist agenda,

2003.

56 See Mesut Yeğen, Müstakbel Türk'ten Sözde Vatandaşa (Istanbul: Metis, 2006).

57 Henck, Subcommander Marcos, 187, has commented that it "is highly significant that Marcos chooses the word 'event' and not 'rebellion,' 'revolution,' or 'uprising' to describe the seizure of San Cristobal." 
such as the Education Workers' Union (Eğitim-Sen), the Human Rights Association (İHD), the newspaper Özgur Gündem, and women's associations such as Selis. These are considered to be manipulated by the PKK. It may be true that the PKK directly or indirectly controls or influences some of the pro-Kurdish organizations operating within the political and social field in Turkey to a certain degree. But Barkey has drawn attention to the fact that Kurdish parties "never developed, contrary to the government's claims, the kind of organic relationship which exists between the IRA and Sinn Fein in Northern Ireland, where the latter does not hide the fact that it is the political arm of the armed militants." ${ }^{28}$ Thus, the "sedimentation" of discourses and practices instigated by the forceful insertion of Kurdish identity into a homogenized national imaginary cannot be overlooked without paying the price of producing incomplete, biased and faulty analysis.

The early 1990s is the period in which the Kurdish "micro-space" that had emerged in the 1960s in Turkey's southeastern provinces became "firmly rooted in the Turkish political arena." 59 This marked the opening of differential political and social spaces within the territory of the nation-state. Not only had the Kurdish war become a constant item on the country's agenda, but successive Kurdish parties were also scoring unusually high in the southeastern provinces in general elections. HADEP, the third legal Kurdish party after HEP and DEP, for instance, obtained only 4.2 percent of the nation-wide vote, but scored as high as 46.7 percent in Diyarbakır, 37.4 percent in Van, and 54.3 percent in Hakkari in $1995 .{ }^{60}$ This amounted to about a million vores which, as Barkey has rightly observed, conferred some degree of legitimacy to the party. ${ }^{61}$ No other mainstream party could equal this performance in cities considered to be the main bastions of Kurdish nationalism.

Thus, two different electoral dynamics began operating in the country, one national and the other regional. In the March 2009 local elections, for instance, although the DTP obtained only 5.68 percent of the national vote, it won the mayor's seat in one metropolitan city (Diyarbakir) and seven provincial capitals in the Kurdish region. In Hakkari, it scored as high as 78.97 percent. The ruling Justice and Development Party (AKP) had poured significant resources into competing with the DTP in the eastern and southeastern provinces, especially for the Diyarbakır metropolitan municipality, in order to capture this "Kurdish bastion";

58 Barkey, "HADEP," 131.

59 Hamit Bozarslan, "Turkey's Elections and the Kurds," Middle East Report, no. 199 (1996): 16.

60 Ibid.: 18

61 Barkey, "HADEP," 129. 
instead, it ended up losing even the municipalities that it had previously held. ${ }^{62}$ The Kurdish provinces, then, were behaving and reacting differently from the rest of the country. This Kurdish "micro-space" owed much to the spectacularity of the heightened war and the serbildans. These were literal incisions into a national public space that had been regimented by the 1980 putsch. ${ }^{63}$ Although the Turkish establishment was not yielding to demands for recognition, a de facto recognition was already taking place. The PKK, Kurdish legal parties, and the Kurdish constituency in the Southeast had become part and parcel of politics in Turkey. They had become factors to be dealt with, to be struggled against during elections, to be taken into account when drafting party programs, and so forth.

Chiapas did not become a "micro-space" in the electoral sense, since the Zapatistas boycott representative democratic mechanisms. It became an autonomous zone no longer controlled by the central government, however. The visitor to the region is stunned by the presence of an informal border: the Zapatista flag is stretched across the wall of the first village house, and a sign post reads: "Zapatista Village. It is forbidden to introduce alcoholic beverages, drugs and other illicit articlesCommittee of Good Government." This is not a simple enclave detached from the rest of the country. The Zapatistas intend for it to be a model of self-government to be imitated elsewhere in Mexico and in the world. More importantly, the language of indigenous rights has started circulating in Mexico, owing to the Zapatista prowess in bringing the government to sign an accord, as will be elaborated on below.

Yet, the unspectacular struggle to build alternative political, economic, educational, sanitary and judicial structures in Chiapas does not seem capable of prompting as much publicity as, say, the question of the real identity of Subcommandante Marcos. Moreover, neither movement overturned the regime against which it was fighting. However, the impact of both movements on discourses and practices beyond their immediate circles cannot be evaluated without considering the aftermath of the uprisings. After having inserted themselves into the authoritarian political spaces in their respective countries, the two movements were able to establish extensive networks and thereby jump scales, each in its own particular manner, thanks to the places that they built as strongholds-namely, Diyarbakır and Chiapas.

62 "DTP Güneydoğu'da Ezdi Geçti," Radikal, 30 March 2009

63 The military regime that came to power on 12 September 1980 banned all political parties, almost totally eradicated the Left, closed down trade unions and associations, and censored newspapers. 


\section{Two different dynamics of place-making}

As stated at the outset, what I call "place-making" provides a convenient framework through which the less visible or discernable effects of a social movement on societal processes may be studied. The "complex processes through which discourses [...] deployed in moments of collective organization and protest become translated and socially embedded by a variety of actors, not only over time but through disparate social and political arenas" ${ }^{14}$ followed a comparable logic in Mexico and Turkey.

After the capture of Öcalan, the main institutional structures of the Kurdish movement were the 38 municipalities obtained by HADEP in the 1999 local elections, eight of which were metropolitan. ${ }^{65}$ I have argued elsewhere that the impact of this electoral victory was not political in the narrow sense of the word, but mainly cultural and social. ${ }^{66}$ Particularly in Diyarbakır, the municipality became the force that moved the city out of its devastated and sinister existence after fifteen years of a "low-intensity war." Without the institutional weight of the municipality as a counter-force against the central state institutions in the city, the transformation could not have been as impressive. I will briefly outline this transformation, since it demonstrates how place-making is not only about appropriating a physical place, but also about (re)constructing a movement.

Diyarbakır severely suffered under the State of Emergency declared in 1987. Public activity was restricted by strict curfews and surveillance. Hundreds succumbed to "extrajudicial executions" that were sometimes carried out in broad daylight. The forced evacuation of villages in the region had tripled the size of the ciry's population; infrastructure and sewage systems fell drastically short of serving the population's needs. Unemployment rose to as much as 60 percent in the winter when no seasonal work was available in other regions. These material difficulties worsened the trauma of war and loss. ${ }^{67}$ Evidently, the government was not inclined to provide any financial or social aid. The first HADEP mayor had to seek funds from the EU to invest in much-needed infrastructure. It became the first public institution since 1980 to tend to such basic needs as garbage collection or the provision of clean water in the city. The municipality thus contributed to the (re)constitution of the

64 Nelson, "Decentering the Movement," 559.

65 http://www.yerelnet.org.tr/secimler/?tur=\&yil=1999. In the 2004 local elections, the re-named Kurdish party obtained 56 municipalities in the region.

66 See Gambetti, "The Conflictual (Trans)formation."

67 For more on trauma and post-war difficulties, see Dilek Kurban et al., Coming to Terms with Forced Migration: Post-Displacement Restitution of Citizenship Rights in Turkey (Istanbul: TESEV, 2007). 
discourse of social needs, while at the same time dispelling the effects of the strict separation of the public space into "the state vs, the people." It filled in the gap left open by the lack of willingness of the central administration to heed local demands.

The municipality also used its legitimacy to boost various social and civic actors that had been trying to open up niches for themselves in the polarized public space. It enabled the local yourh to form theater or music groups; it inaugurated a festival that brought local and national artists together; it used shrewd tactics to dodge the ban on celebrating Newroz, the Kurdish New Year, and actually turned the event into a festivity attracting popular Turkish singers and hundreds of thousands of spectators. It invited social and cultural associations from other regions in Turkey to propose projects to deal with the city's multiple needs (such as dealing with homeless children), or encouraged those who wanted to set up their own private institutions (such was the case of the now fully established Diyarbakır Cultural Center).

In fact, the 2000 Newroz celebrations disturbed the chain of significations that split Turkey's symbolic space into two. Instead of functioning as a signifier that constituted and reinforced the frontiers of the two camps (pro-state and pro-Kurdish), Newroz became the ground for a mutual struggle - for recognition on the part of the Kurdish movement and for hegemony on the part of the state. This altered the symbolic value of Newroz for both Kurds and Turks. Although still representing Kurdish cultural identity for the Kurdish movement, it became a festivity instead of a site of violent antagonism. As for the Turkish public, Newroz no longer retained its threatening connotations and began to be celebrated as well, albeit in physical places apart from the Kurds.

On a more physical level, the next Kurdish mayor of the DEHAP (the party's name had changed in between) engaged in the city's decolonization. The re-investment of the city as a place with a new imaginary was facilitated by the 1995 initiative of a civil society organization to mobilize several public institutions around a project to restore the ancient city walls. ${ }^{68}$ By 2003 , the walls were the central elements of a campaign to get Diyarbakır listed under the Seven Wonders of Anatolia Contest sponsored by a private entrepreneur. The walls came to represent a history that went unacknowledged in Turkish nationalist discourse and historiography. The consecration of the ancient walls thus had the double effect of constructing local pride as well as transcending it. The confines of the local and the particular were transcended in

68 Şeyhmus Diken, Güneydoğu'da Sivil Hayat (|stanbul: Metis, 2001), 97.98. 
such a way as to articulate Kurdishness into world cultural heritage (the universal or the global). I have also dealt with this elsewhere. ${ }^{69}$ Suffice it here to note that the Turkish Republic was quire successful in effacing the traces of the "Other" in the eastern and southeastern provinces where Armenians, Kurds, Syriacs, Arabs and other ethnies had lived for centuries. ${ }^{70}$ Diyarbakır was one of the privileged targets of such erasure strategies, since the first Kurdish rebellion in the history of the Republic had taken place there in 1925. The recent renegotiation of Diyarbakır's culture and history constructed a foothold on Turkish territory for a Kurdish identity that now imagined itself through its cultural heritage rather than its armed uprising. The city thus became the informal Kurdish capital and was invested with new meaning.

These and other details, the enumeration of which is redundant here, show how the materialization of a new discourse of social, cultural and urban needs became the nodal point marking the dispersion of former antagonisms in favor of a more fluid constellation of forces. This placemaking also had an impact on the subsequent evolution of the Kurdish movement. As I shall show below, not only did this modify the set of actors within the movement, but it also changed its discourse. The spatial transgression that eventually turned Diyarbakır into a "Kurdish bastion" was not an incidental feature in the emergence of a wider social movement, it was part and parcel of the construction of practices of resistance. Diyarbakır, when invested with symbolic meaning, became a mobilizing factor, much in the way of the Plaza de Mayo. This demonstrates indeed that the "symbolism of a particular place can be 'mobile."71

Events followed a different course in Chiapas. What happened there points to another dynamic, a rural one in this case. As opposed to the urban needs and structures to which the Kurdish movement was responding, ${ }^{72}$ the zones controlled by the Zapatistas in Chiapas were populated by severely impoverished peasants whose needs were much more basic and vital. Chiapas is one of Mexico's poorest states. As is true of Turkey's Sourheast, it suffers from neglect, willful devastation

69 Zeynep Gambetti, "Decolonizing Diyarbakır: Culture, Identity and the Struggle to Appropriate Urban Space," in Comparing Cities: The Middle East and South Asia, eds. Kamran Asdar Ali and Martina Rieker (Karachi: Oxford University Press, 2009).

70 See particularly Kerem Öktem, "Incorporating the Time and Space of the Ethnic 'Other': Nationalism and Space in Southeast Turkey in the Nineteenth and Twentieth Centuries," Nations and Nationalism 10, no. 4 (2004).

71 Bosco, "Madres de Plaza de Mayo," 323.

72 The PKK and the subsequent Kurdish movement have a much more urban basis today, owing to massive forced migration (of around one million people) from rural areas to cities in the eastern and southeast regions, as well as to the West and South of the country. The largest urban population of Kurds is concentrated in Istanbul. 
and rampant corruption. But the EZLN did not aim to found a separate state, as did the PKK. The Zapatistas requested that the indigenous be granted official recognition, that their rights be guaranteed by law, and that their living conditions be improved. Yet, they linked the issue of indigenous rights to two other concerns from the very start: to the indigenous communities' right to self-determination, and to the struggle against neoliberalism. In orher words, their aim was to simultaneously bring the indigenous out of oblivion, stop multinationals from devastating Mexico's resources, and obtain official recognition for a form of political organization that the indigenous had been using for centuries.

The first phase of the uprising ended in February of 1996 with the signing of the San Andres Accords, actually only a small portion of what the Zapatistas had proposed at the beginning of the talks. The accords, in fact, were intended to recognize cultural and ethnic pluralism in Mexico, but in a way that linked this issue to the indigenous communities' right to self-determination. The government pledged to incorporate these rights into the constitution. It also promised to take measures to enhance the political representation of the indigenous, provide for their participation in the judicial system, recognize their customary systems of justice (usos $y$ costumbres), and provide for the sustainability of the communities. ${ }^{73}$ By the end of the year, President Ernesto Zedillo had already betrayed the EZLN. It then became clear to the Zapatistas that the only solution to implementing the San Andres Accords was to implement them on their own, "right here and now," without depending on the federal administration's good will (which they proved not to have).

The second to fourth phases of the uprising thus took the form of the establishment of autonomy in the 38 municipalities that the Zapatistas controlled. ${ }^{74}$ Phase two saw the formation of the five coordinating centers called Aguascalientes and the pooling of resources through a community labor tax. The government's official representatives and authorities were expelled in the third phase. Starting in July of 2003, the fourth phase launched a regional structure of autonomous government: "Each autonomous municipality now sends rotating representatives to one of the five regional Juntas de Buen Gobierno based in the Caracoles that replaced the old Aguascalientes." 75

73 Gloria Munoz Ramirez, Ateş ve Söz. 20. ve 10. Yilinda EZLN (Istanbul: Ayrinti, 2005), 53-54.

74 Richard Stahler-Sholk, "Autonomy and Resistance in Chiapas," in Dispatches from Latin America: On the Frontlines against Neoliberalism, eds. V. Prashad and T. Ballve (Cambridge: South End Press, 2006), 220-221.

75 Ibid., 221. Juntas de Buen Gobierno literally translate as Committees of Cood Covernment-as opposed to Bad Government, that is, the federal one. 
The idea of the conch contains the gist of the Zapatista place-making process. This is how Subcommandante Marcos has expressed the idea:

I want to tell you about an architectural masterpiece that was born on the skirts of the then-living Guadalupe Tepeyac, in July and August 1994. The Tojolabal architects-for the most part illiterate, their most "educated" having made it to third grade-raised a masterpiece in twenty-eight days, to house what the Zapatistas called the $\mathrm{Na}$ tional Democratic Convention. Honoring Mexican history, the Zapatistas called the meeting place Aguascalientes. [...] When the time came to deal with the hostels, the library, and the other facilities, the rebel Zapatista Tojolobales-the impromptu architects-began to build structures that sprinkled the immediate surrounding of the gigantic auditorium in what appeared to be a great disorder [...] you had to fly very high to discover the Zapatista conch tracing its spiral on these poor rebel lands. [...] The Aguascalientes conch was the place of the encuentro, of the dialogue, of the transition, of the search. From what "architectural" tradition did the indigenous Zapatistas borrow? I don't know, but surely that conch, that spiral, invites entry as well as exit, and really, I would nor dare to say where a conch ends or begins. ${ }^{76}$

These structures, renamed Caracoles (conches in Spanish), physically stand in the middle of the Zapatista communities. To simplify this somewhat, the social and political order functions according to a horizontal network of villages that are then linked vertically via a system of delegation (but not representation) at three different levels: that of the municipio, the region, and the caracol. The caracol is both the meeting place for the communities and the seat of the autonomous governments. Because most Zapatista communities are rural, the caracoles are situated at convenient distances from the pueblos grouped under them. They have all been added to the landscape, rather than being constructed out of already existing residential structures. They all contain similar buildings and facilities, such as an audirorium, a clinic, a school, and administrative offices. People from different villages come together here to sit in assemblies that discuss communal needs and devise solutions. The conch is thus physically porous: it is not inhabited by anyone, but this is where community power is wielded. Unlike a municipality or govern-

76 Subcommandante Marcos. "The Conch of the End and the Beginning (Neoliberalism and Architecture or The Ethics of the Quest Versus the Ethics of Destruction)," in Our Word is Our Weapon. Selected Writings, ed. 1. Poncé de Leon (New York: Seven Stories Press, 2002). 
ment in the common sense, the control of a caracol is not won or lost through elections, but constantly held by all communities attached to it. The caracoles, then, are outright spatial transgressions, as they disrupt the "formal" spatial ordering of the Mexican regime into states, regions, municipalities, and circumscriptions.

According to Subcommandante Marcos, the EZLN's vanguard ideology was largely altered upon contact with the indigenous populations in Chiapas. The guerillas had to learn how to listen and understand: "what had been a classic revolutionary guerilla war in 1984 [...] by 1986 was already an armed group, overwhelmingly indigenous, listening attentively and barely babbling its first words with a new teacher: the Indian peoples." 77 There was, in fact, a mutual dependence between the guerillas and the indigenous populations. The guerillas did not trust the indigenous for fear of being denounced, but needed them in order to survive in the jungle and also in order to set up an army. The indigenous did not trust the guerillas for fear of being dragged into a rank-and-file guerilla army, but needed them in order to learn how to defend themselves against government raids and paramilitary activity. "In order to survive, we had to translate ourselves using a different code [...] this language constructed itself from the bottom upwards," writes Marcos, adding that the indigenous "have a different substratum, a complex prehistory of uprisings, so we modified our approach interactively." ${ }^{.78}$ This is how the EZLN slowly gave birth to the social movement that calls itself "Zapatista," and the conch was devised to symbolize autonomy as well as the absence of leadership.

What needs to be emphasized first and foremost is the type of power that the Zapatistas constructed in the territories that they had retracted from the grip of the state-party, the PRI. By refusing to make claims on federal state power, the Zapatistas were actually eschewing political forms thought to be inescapable. Alternative structures were set up during the initial phase of negotiation between the armed intellectuals that were out to revolutionize Mexico and the indigenous populations inhabiting the Chiapas for centuries. The place for politics that emerged in the decade-long creation (1984-94) of a common understanding and a common strategy is characterized by structures that contain the promise of being anti-structures. To be sure, the Zapatistas have set up an order; they are in no way anarchists in that sense. But what is peculiar about this order is that it necessarily allows for indeterminacy, owing to its very 
structure. Given the imperatives of capital and its historical (and constiturive) relation to the modern state, the place produced by the Zapatistas works as a potential antidote to the formation of hegemonies or patterns of domination. The particular organizational form of the councils-the rejection of representative democracy or party politics, the multiplication of venues of participation, the deprofessionalization of administrative tasks-breaks with the kind of political structure in which capitalism has historically thrived. As such, place becomes the means of struggle, an active force determining the form that the resistance will take, just as much as place-making becomes the object of struggle. To put it differently, place is a means as well as an aim, a constituting force as well as a constituted one.

This actually accounts for the staying power of the Zapatistas: thirteen years have elapsed since the initial uprising. A form of organization of all spheres of life has been found that continually instigates reflection concerning the community at large while allowing for individuation. The articulation of places (the pueblos) to the whole area of Chiapas as controlled by the Zapatistas is such that a constant flow of communication can be secured. This structure not only enables the confrontation of individual demands with communal ones, thus allowing negotiation to take place between the two, but also produces subjectivities that become fine-tuned to the linkages between scales. From building a bridge to determining what courses will be taught in community schools, decisions are taken together in assemblies. ${ }^{79}$ Questions exceeding the capacity of the pueblos are referred to higher units, but ultimately the pueblo has the right to accept or reject the final decisions made at these levels. Alternative economic solutions have been devised that allow for a pooling of resources, which preserves the right of individuals to land, resources and consumption, while catering to the common good.

The places that were modified by the Zapatista movement did not carry the traits of the more centralized, compact and architecturally visible urban model of change seen in Diyarbakır. ${ }^{80}$ Rather, they were

79 For a very detailed description of the activities taking place in each caracol, see Gloria Munoz Ramirez, "Chiapas, La Résistance," Réseau d'information et de solidarity avec l'Amerique Latine (2004), http:// risal.collectifs.net/article.php3?id_article $=1194$.

80 My observations and interviews in the field revealed that, before the seizure by the Zapatistas, a kind of apartheid was practiced in San Cristobal, the largest city in Chiapas. Indigenous people were not allowed to reside in the city center, nor were they allowed to walk on the sidewalks which were reserved for the non-indigenous. Now, the city is literally flooded by the Chamula Indians who are not Zapatista, but who have benefited from the newly acquired status of the indigenous in Mexican society. In comparison, Oaxaca, the capital of a region where Mexico's largest number of indigenous peoples lives, is still dominated by the "white." 
modified because of their being incorporated into a new structure of autonomous administration. Daily life in the pueblos is linked to an expanding spiral (much like the metaphor of the conch) of lives within and beyond the community. In other words, constructing a place-that of Zapatista autonomy - in Chiapas is an integral part of the Zapatista movement.

But, as much as place-making in a field of hostile forces is a clear sign of the strength and vigor of a movement, as Stahler-Stolk has rightly pointed out, there are a number of pitfalls related to the model of autonomy. Among these is the danger of regional "bossism," of being trapped in a "self-policed homeland" with limited resources; of "the potential for the neoliberal state to pass off responsibility for the unprofitable provision of public goods to autonomous,' but underfunded units"; of the creation of "new mechanisms for division and cooptation" and of "managed neoliberal multiculturalism"-that is, of "the neoliberal model's recognition of a plurality of indigenous identities, as long as those identities do not become the basis for collective organization around substantive rights." ${ }^{\prime 1}$

On another note, the Zapatistas' capacity for maneuvering in the Mexican domestic arena is curbed by two factors: (1) All negotiations with the government or strategic moves are debated in assemblies before being implemented. This also accounts for why the war ended in twelve days: the indigenous communities decided that enough blood was shed. (2) Catering to the needs of the communities takes up an enormous amount of time and energy and thus turns Zapatista ingenuity inwards rather than outwards.

It is therefore important to assess the broader effects that the two movements have had beyond the places which they had reinvested with a new identity and relationship structure. Of particular interest for the purposes of this paper is how the two movements managed to "jump scale," thus extending their networks beyond their particular locality. In strict correlation stands the question of innovation, change and disruption in the repertoire of action and symbolism available to the movements. This is particularly relevant if we accept that national security discourses, coupled with global neoliberal assaults on previously uncommodified assets and resources, have dealt a blow to individual and group rights. It may well be that democratization is no longer tantamount to institutional arrangements at the national level. Market forces serve to dispossess citizenry not only through aggressive accumulation process-

81 Stahler-Sholk, "Autonomy and Resistance," 222-223. 
es, but also by forfeiting collective decision-making via the discourse of "necessity." How, then, do the Kurdish and Zapatista movements relate to the transformation of political and economic structures? This is what needs to be evaluated, albeit only suggestively.

\section{Appropriation of space in a neoliberal world}

At this point, assessment is not an unproblematic task and needs to be nuanced. Neither the historical and cultural context within which the two movements have emerged, nor the power structures against which they have had to struggle allow for easy comparison. For the purposes of this paper, which is avowedly limited in scope, I will content myself with making a few remarks concerning certain visible signs of network formation and "sedimentation."

\section{The Kurdish/democratization movement}

The Kurdish uprising turned "national" with the foundation of legal parties and organizations. When the war subsided and the prospect of joining the EU created an atmosphere of euphoria receptive to democratic demands, the Kurdish movement expanded considerably to include nonKurds, a sizeable portion of the Left, the Turkish intelligentsia and civil sociery activists. Meanwhile, torture victims and the victims of forced evacuations were forming associations to express their grievances and demands. Such activities were particularly important as they appealed to the general Turkish public. The privatization of television broadcasting and the creation of the pro-Kurdish Med TV have also been influential. $^{82}$ Through satellite broadcasting, Med TV (now renamed Roj TV) managed to open up a space in which Kurdish culture and politics could find a non-official medium of expression.

All this has significantly altered the field of civic activism as well as its actors. Most important of all was the rapprochement enabled by the Kurdish municipalities between leaders of the Kurdish movement and democracy activists elsewhere in Turkey. Diyarbakır was where these started to meet each other, sit on panels and consider cooperating around concrete social projects. As suggested above, place-making played a key role in network construction. Before anybody else from the Kurdish movement, the DEHAP metropolitan mayor of the city, Osman Baydemir, began to receive invitations to İstanbul from formal or informal activist circles. Baydemir's discourse differed both from that of

82 See Amir Hassanpour, "The Creation of Kurdish Media Culture," in Kurdish Culture and Identity, eds. P. G. Kreyenbroek and C. Allison (London and New Jersey: Zed Books, 1996). 
the national leaders of DEHAP and from that of the PKK. Ever since his election to office, he called for the establishment of the conditions necessary for Turks and Kurds to live together peacefully. Despite his being constantly stigmatized by the dominant media, Baydemir also made the first moves in the way of investing the mayor's office with new functions. Under his initiative, for instance, nine DEHAP mayors proposed a "Fraternity Law" as an alternative to the state's "Amnesty Law" to PKK militants who have not yet laid down their arms. ${ }^{83}$ In doing so, the mayors were not only acting as popularly elected representatives of their constituencies, but also as if they were deputies from the party at the national level. Indeed, the Diyarbaktr mayor went on a tour of several European capitals before the 17 December 2004 EU summit in which Turkey's capacity to fully adhere to the EU's criteria was evaluated. He pleaded in favor of Turkey's adherence. ${ }^{84}$ Without doubt, this was a step out of everyday biopolitics to link the local to national and international levels. More importantly, the mayors were moving beyond the available political structures and repertoires to define a new trajectory.

The highly centralized, bureaucratic and rigidly ideological structure of the Turkish establishment (including the mainstream media) started countering these moves by inventing new threats to national security and instigating a wave of nationalist hysteria, lynching attempts and flag furies. ${ }^{85}$ For every new "opening" (such as the controversial conference on the Kurdish question by leading figures of the Kurdish movement and prominent Turkish intellectuals), there were backlashes of varying intensity, including raids into Northern Iraq. The Turkish political arena was the scene of a literal tug-of-war between democratic and reactionary forces between 2005 and 2009.

Despite this, the DTP succeeded in obtaining 23 seats in parliament in 2007.86 Thus, the parliament became one of the arenas in which

83 "DEHAP Çözüm Arayışında," Radikal, 21 April 2005.

84 When journalists asked Prime Minister Recep Tayyip Erdogan after the EU summit whether he would thank Baydemir for his efforts, his answer was negative. Baydemir admitted to being frustrated by the lack of recognition for the role he chose to play to appease European fears about Turkey's Kurdish question. Interview by author with Osman Baydemir in Diyarbakır, 17 January 2005.

85 Zeynep Gambetti, "Linç Girişimleri, Neo-Liberalizm ve Güvenlik Devleti," Toplum ve Bilim, no. 109 (2007).

86 Unlike Mexico where a single party dominated the electoral outcome over the past century, Turkey's political system accommodates a considerable degree of ideological diversity through electoral channels, even with a 10-percent national threshold. Fourteen political parties and 772 independent candidates competed against each other in the 2007 elections. Although the Left has always been the one ideology excluded from parliament owing to the 10.percent hurdle, the ultra.right and the Islamists have obtained representation alongside social democrats, liberals and republicans. The current parliament includes members belonging to four political parties, including the DTP and four independent deputies. 
democratic struggle was staged. Although the 23 DTP deputies were under pressure from all sides to prove that they had no organic links to the PKK, they eventually came to be accepted as the representatives of the Kurdish population in Turkey. Their having voiced "scandalous" ideas from the parliament floor-for instance, "why should we deny that the PKK is a reality in this country?" 87 - has led to legal moves to remove their immunity and ban the party. As opposed to the plight of the HEP/DEP, however, such moves triggered considerable opposition from among civil society activists. The organization Stop Racism (Irkf̧ilığa Dur De) sent activists to DTP's parliamentary group meeting in January of 2008 in a display of solidarity. The spokesperson for the organization said: "We have come to lend you support against both Turkish and Kurdish nationalism [...] against the onslaught or sabotage of any kind of nationalism; we have come to lend you support against those who try to set you off the track of becoming [a representative of all of Turkey]."88

Stop Racism might actually have been expressing what a considerable portion of democrats and other progressive Turkish circles seem to be thinking: the Kurdish movement is the only major social movement in the country capable of standing at the same time against the establishment and the two other mass movements, the ultra-nationalists and the Islamists. The labor movement has not been able to reorganize itself after the devastating effects of the 1980 military coup. The prospect of an EU-incited democratization process has also dimmed, given the resistance within the EU to Turkey's full membership. Most radical democrats and left-wing intellectuals in Turkey are therefore pinning their hopes on the Kurdish movement as the only potentially democratic force available at present. They are spending a great deal of energy to establish a dialogue with renowned Kurdish figures. At times, the dialogic process turns into a monologue whereby Turks start dictating to the Kurds what they should do, like condemning all types of militarism, including the PKK's. ${ }^{89}$ Notwithstanding the ups and downs, these "dialogues" have concretized in a series of peace conferences convening in six metropolises throughour Turkey from 2003 onwards and the

87 "Sakık: PKK Bu Ülkenin Gerçeği ve Meclis'te de Konuşulmalı," Radikal, 6 December 2007.

88 "DTP'li Türk: Kürtler 4 Bin Vıldır Bu Topraklarda, Azınlık Değildir," Radikal, 9 January 2008.

89 This process whereby members of the dominant ethnie try to command the minority which they ironically want to transform into their saviors was most evident in polemics taking place in the Sunday supplement of the more or less democratic newspaper Radikal. Similar attitudes have been observed during the Conference on Turkey's Kurdish Question, organized on 11-12 March 2006, at Bilgi University in Istanbul. Likewise, the Peace Initiative Group seems to be split on the issue of whether the state or the PKK should first be called upon to lay down arms. 
subsequent formation of a "Peace Assembly" in 2007. Uniting the new actors engaged in fostering a democratic resolution of the Kurdish question, this informal assembly tries to coordinate activities aiming, among others, at: ending armed conflict; fighting discourses that stigmatize the "Other"; removing the institutional and legal hurdles in the way of full participation of Kurds as "active subjects of the political arena"; devising plans to reduce poverty and inequality in the Southeast; removing bans on the use of the Kurdish language; and calling the mainstream media to question its role in perpetuating an atmosphere of hatred and mistrust. ${ }^{90}$ The assembly is not an officially recognized structure, unlike the National Indigenous Congress (CNI) in Mexico, but it centralizes and institurionalizes democratization efforts. Another significant novelty in the Turkish political scene is the will to form an umbrella party (Catı Partisi) to allow several small opposition parties to join forces. A strategic alliance was already formed during the 2007 elections, whereby Kurdish and leftist parties jointly put forward independent candidates. Last but not least, as this paper was being finalized, a sudden and relatively unexpected "opening" materialized under the auspices of the ruling pro-Islamic party, the AKP, who launched a so-called "democratic initiative" that set the political scene ablaze in an effort to solve the "Kurdish problem."

As important as these parliamentary, institutional and societal developments may be, two grandiose issues were left unresolved in this process: (1) No language other than that of poverty reduction and developmentalism was used in assessing the economic aspect of the problems in the Southeast. (2) No language other than that of statist politics and instrumental negotiation was used in offering a solution to the Kurdish question.

To be sure, the long and painful struggle of the Kurdish movement sedimented in various discourses and practices. The most notable ones are debates over cirizenship (replacing the word "Türk" [Turk] by "Türkiyeli" [of Turkey] to denote the citizens of the Turkish Republic), the right to education in the mother tongue, and the representation of $\mathrm{mi}$ norities on state television. Apart from provoking self-reflection among Turks, the movement also played a major role in revealing the dark side of the state, particularly its contra-guerrilla and anti-terror activity. The emergence of signs of anti-militarism in a society where every man is considered a "soldier by birth" can undoubtedly be imputed to the suf-

9० Bianet, "Amaç Barışı Kuracak Toplumsal Örgütlenme," (2007), http://www.bianet.org/bianet/insanhaklari/g0221-amac-barisi-kuracak-toplumsal-orgutlenme. 
ferings caused by fifteen years of civil war. In step with the global trend, multiculturalism (or rather an estheticized interest in minority cultures) also became popular among the urban elite. Concrete concessions made by the government were the launching of a Kurdish-language television channel (TRT 6) and beginning to encourage the establishment of Kurdish studies in universities.

However, state authorities, elected representatives and the wider public still think and act through strict dichotomies such as Turk/Kurd, terrorist/pacifist, and threat/security. This can partially be accounted for by looking at how regional dynamics circumscribe the spaces of action available to the Kurdish movement in Turkey. The PKK, for instance, is operating in a highly volatile region, the Middle East, which has been and still is of formidable interest to imperialist powers, mainly owing to its petroleum reserves. In addition, the Middle East is particularly lacking in historical experiences of autonomy due to having long been subdued under Ottoman dominion, although endless power struggles have marked its past. In contrast, although Central America has also had its share of successive imperialist interventions, the traditional indigenous types of communal organization and the revolutionary struggles that founded modern Mexico have provided a practical and justificatory foundation to collective acts of defiance. ${ }^{91}$ Another reason is surely the "Sèvres syndrome," or the fear of dismemberment, from which large segments of Turkish society have suffered ever since the end of World War I and which politicians use and abuse at will.

As the expectation that EU membership would finally bring about democratization dimmed, it became evident that any substantial change would have to be achieved without foreign assistance, despite the abovementioned volatility of the country and the region. The DTP's electoral success could have been used as leverage to expand the democratic spaces already appropriated and to initiate a full-fledged grassroots movement. This has nor materialized yet. In its self-critique after the 2007 elections, the DTP succinctly summarizes its lack of vision:

We could not transform the pluralist structure of the party into an asset. Rather than instigating radical democracy by ourselves, as we should have done, we were stuck in the position of complaining about why the state does not democratize itself. ${ }^{92}$

91 Maria Fernando Paz, "Searching for Root Causes: A Historical Background Sketch of the Protagonists of the Zapatista Uprising," Identities 3, no. 1-2 (1996).

92 Bianet, "DTP: Ezilenlerin Sesi Olmayı Başaramadik," (2007), http://www.bianet.org/bianet/ siyaset/100883-dtp-ezilenlerin-sesi-olmayi-basaramadik. 
Caught up in the very power structures that they are seeking to alter, the groups in the present Kurdish movement are in a way reinforcing the centrality of the state as the sole decision-making and resourcedistributing mechanism. They still continue to employ the discourse of "sides" (Turkish and Kurdish, the state and the PKK), for instance. Several actors, including the DTP, offer to serve as intermediaries. This reproduces the idea of a split society, instead of rendering the conceptual boundaries more fluid and porous. The general discourse is one of feasibility, political pragmatism and party-based politics. Petitions, public demonstrations and closed conferences or workshops among elites are about the only forms of political action devised by the movement. Little or no alliance exists between the Kurdish movement and other minorities living in Turkey. ${ }^{93}$ The "Edi Bes $e$ " campaign, obviously instigated by the PKK leadership, has adopted the Zapatista slogan "Ya Basta" (enough), but only to ask for the liberation of Öcalan. ${ }^{94}$

Moreover, there is absolutely no effort, either on the part of the Kurdish elite or of the civic organizations which are part of the movement, to counter the effects of the neoliberal transformation. For instance, Diyarbakır has become a base for lucrative undertakings and projects for the private sector. There abound micro-credit schemes that tend to discipline an economically desperate population in accordance with the necessities of the neoliberal market economy. Infrastructural projects and arrangements related to the needs of forced migrants, projects to provide for a return to the villages, economic and industrial concerns, poverty, illiteracy, women's problems, and health are biopolitical problems that no one feels the need to address in novel, participatory or communitary ways. The ultimate purveyor of livelihood and employment is still thought to be the state. Instead of using violence and intimidation, the latter is more and more subscribing to governmental schemes likely to bring about subjugation through subtle disciplinary practices and through the development of consumption culture. No alternative sustainable agricultural vision is being discussed to struggle against the neoliberal onslaught on the farming sector.

Thus, the coordinated efforts described above remain at best elitist and at worst unable to detach themselves from a state-centered idea of

93 Ahmet Türk, the leader of the DTP, did not refrain from distinguishing the Kurds from other minorities on the grounds that the "15 million Kurds living on these lands for 4,000 years are one of the two peoples who form the main pillars of the Turkish Republic," ("Kürtler Azınlık Değildir.")

94 Medyaname, "KCK Yürütme Konseyi Üyesi Duran Kalkan PKK Bundan Sonra Ne Yapacak Sorusunu Yanitladı," (2007). http://www.medyaname.com/tr/index.php?option=pek_content\&task=view\&id=1 049 \& Itemid $=1689$, accessed on 5 September 2008. Ocalan is said to have been very much inspired by the Zapatista uprising when devising his idea of a "democratic-ecological society" in 2003. 
justice and democratization. Unlike the Zapatistas, the new Kurdish -cum-democratization movement is devoid of an alternative political and economic imaginary.

\section{The Zapatista/autonomy movement}

What distinguishes the Zapatistas from the Kurdish movement is ultimately the former's refusal to abide by either liberalism or neoliberalism. As described above, the Zapatistas' alternative political vision has led them to develop a much broader concept and practice of democracy. Representative democracy, however liberal it may be, is not sufficient in the eyes of the EZLN:"The Zapatista concept of democracy is something that is built from below, with everyone, even those who think differently from us. Democracy is the exercise of power for the people all the time and in all places." 95 The various elections boycotted by the EZLN have caused considerable frustration for the opposition party PRD. Nevertheless, the EZLN's refusal to be "representative" of a faction within Mexican society stems from the conviction that current political structures, rather than being solutions, are responsible for creating the problems facing the poor, the excluded and marginalized, the oppressed and exploited. This partially explains why the Left keeps a skeptic eye on the Zapatista experience. Instead of aiming to take over state power and use it for revolutionary ends, the EZLN's grand ambition is to change the very structures of power-including those of economic power. Using them would in fact amount to justifying them. The Zapatistas' idea of struggle involves revolutionizing power right here and now. In other words, the means are made to conform to the desired end. One close observer of the movement has commented that the Zapatistas' political vision is a "modern proposal that, like a group of small particules, evades the capturing nets tendered by the ancien régime, concentrating anew on the subtleties involved in seeking attunement between 'the popular' (lo popular) and 'the legitimate' (lo legitimo)."96

The communiqués of the EZLN that circulate on the internet contain ample rhetorical evidence as to the movement's anti-neoliberal stance. But how much has actually changed on the ground remains to be assessed.

As opposed to the PKK, the EZLN has had an international appeal from the beginning. It did not restrict its request to a particular social

95 EZLN, "Communiqué Regarding Elections," (2000), http://flag.blackened.net/revolt/mexico/ ezln/2000/ccri_elections_june.html.

96 Antonio Garcia de Leon, "Chiapas and the Inverting of Established Orders," Identities 3, no. 1-2 (1996): 267. 
or ethnic group; it claimed to be embracing the cause of all oppressed groups and classes, not only in Mexico, but everywhere. The basic demands it made-freedom, justice, democracy, dignity - were so general that they simply invited identification with and espousal of the cause. ${ }^{97}$ The use of the internet and of press releases and open letters by the EZLN, besides earning them the epitaph of "postmodern revolutionaries," was an ingenious strategy to spread the movement beyond the confines of Chiapas. Some interest in the plight of the indigenous in Latin America had already been aroused by massive mobilizations that protested the celebration of the $500^{\text {th }}$ anniversary of Columbus's "discovery" of the Americas. ${ }^{98}$ Building upon this newly acquired terrain, the Zapatistas managed to secure the support of thousands in as few as a fortnight. On 12 January 1994, about 100,000 people gathered in Mexico City's Zocalo to prevent the army from crushing the rebellion. Marcos's pleas to what he termed "civil society" are both an indication of how much the poorly armed forces of the EZLN depended on this "outside" support and of how this very interpellation created the "civil society" that Marcos needed.

This is a perfect example of "jumping scales," as much as of extending the movement's network beyond its immediate locality. As Bosco has argued in the case of the Madres de Plaza de Mayo, these connections help "tap into other networks located elsewhere to obtain critical resources that were locally unavailable to them." ${ }^{99}$ While these connections were more virtual than actual, the international encuentros organized periodically by the Zapatistas from 1996 onwards moved the scale up: physical connections were thus established between the regional (Chiapas) and the global (mainly Latin America, but also Europe and Southeast Asia).

The espousal of the Zapatista cause by activists and collectivities elsewhere in the world indicates that it has become an example, a model that captures the imagination of all sorts of people across different geographies and cultures. As Couch has effectively shown, the anti-globalization movement has been much influenced by this example. ${ }^{100}$ Wallerstein claims further that,

97 In the words of Gloria Munoz Ramirez who was present as a correspondent of La Jornada at the EZLN's first press conference: "Who could ever object to those demands? We all had tears in our eyes as the spokespeople of the EZLN talked." Interview by the author in San Cristobal, 21 July 2007.

98 John Ross, Rebellion from the Roots: Indian Uprising in Chiapas (Monroe, Main: Common Courage Press, 1995). 55-57.

99 Bosco, "Madres de Plaza de Mayo," 319.

100 Jen Couch, "Imagining Zapatismo: The Anti-Globalisation Movement and the Zapatistas," Communal/plural 9, no. 2 (2001). 
[i] $\mathrm{f}$ in the last five years, most South American countries have put left or populist governments in power, the Zapatista example was part of the igniting forces. If the protestors in Seattle were able to derail the 1999 WTO meeting, and were able to follow up with similar demonstrations in Genoa, Quebec City, and other places as well as this year in Gleneagles, they were in no small measure inspired by the Zapatistas. And when the World Social Forum capped this renewal of antisystemic struggle beginning in 2001, the Zapatistas were a heroic model. ${ }^{101}$

The Zapatista movement has been hailed for challenging the idea that "there is no alternative" to liberalism and neoliberalism for redefining democracy as such:

(1)a political democracy based on citizen power in which collective decisions are made without a representational structure; (2) an economic democracy based on structures and relations securing the equal distribution of economic power between citizens and an economic reorganisation of the ownership of the means of production/local taxation by the confederations of demoi, which are based on neighbourhoods/communities; (3) an ecological democracy that will aim to reintegrate society with nature; and (4) a democracy in the social realm (at the places of work, education, the household, erc) ${ }^{102}$

What was missing, of course, was the national level, towards which the Other Campaign, the fifth phase of the uprising, was directed. The question is to what extent the EZLN actually succeeded in mobilizing the rest of Mexico. Although the global space that the Zapatistas have constructed owes to their anti-neoliberal stance and although this stance is vital for any movement's staying power, given the new structures of capitalist accumulation, gaining a foothold at the national level is no less vital. This is precisely because the Zapatistas are a grassroots movement. Without being able to sustain the ground forcefully extracted from the corrupt structures of the Mexican political economy, the movement is bound to lose its support among the indigenous populations whose lives it set out to improve. In other words, failure on the part of the EZLN to modify the actual mechanisms of power in Mexico would lead to its suf-

101 Immanuel Wallerstein, "The Zapatistas: The Second Stage," Commentary no. 165, 15 July 2005, http:// fbc.binghamton.edu/i65en.htm.

102 lair Watson, "An Examination of the Zapatista Army of National Liberation (EZLN) and New Political Participation," Democracy and Nature 8, no. 1 (2002): 66. 
focation in the very physical place that it constructed, irrespective of the symbolic and associative space it might continue to occupy globally.

Apart from peace caravans and symbolic marches, one of the more concrete differences the Zapatistas made in the Mexican political scene was the "National Consultation for the Recognition of the Rights of Indian Peoples and Against the War of Extermination" in 1999. This was the first-ever independent national indigenous organization in the history of Mexico. More than three million people participated in the Consulta in Mexico and several parallel consultations took place among Mexican nationals in the US. This had "the effect of modeling participatory democracy at the national (and transnational) level, and puncturing the military and information siege of Chiapas." ${ }^{103}$ Faithful to their philosophy of "leading by obeying," the EZLN has in fact organized several consultations of this sort with civil sociery. It is therefore possible to claim that the Zapatistas have left an organizational legacy that has been imitated by other groups struggling in different contexts.

On a more legal level, the San Andres Accords provides a basis upon which to pursue demands, although the implementation process has been full of "legislative tinkering," 104 falling significantly short of responding to the demands made by indigenous communities. The lack of political will in regard to the recognition of indigenous cultural and land rights cannot be fully grasped without taking into consideration the economic stakes involved in it. As Higgins points out:

The significance of a neo-liberal governmentality as a challenge to any process of peace in Mexico cannot be overestimated. In terms of neoliberalism, the Cocopas [the Commission for Peace and Reconcilialion in Chiapas, a multiparty legislative body] proposed law effectively represented a means of protectionism for Mexico's indigenous peoples. It attempted to provide both the legal and practical mechanisms by which indigenous culture might not only continue to survive but perhaps even flourish-and in doing so it also placed limits on the capacity of investors and private corporations to take advantage of Mexico's resources, both human and material. ${ }^{105}$

103 Richard Stahler-Sholk, "Clobalization and Social Movement Resistance: The Zapatista Rebellion in Chiapas, Mexico," New Political Science 23, no. 4 (2001): 503.

104 Nicholas P. Higgins, "Mexico's Stalled Peace Process: Prospects and Challenges," International Affairs 77, no. 4 (2001): 898 .

105 ibid.: 900 . 
The EZLN had at the onset linked political with economic issues. The 1992 repeal of land reform legislation was "the straw that broke the camel's back." ${ }^{106}$ In fact, Chiapas had been excluded from the revolutionary land distribution scheme instigated in 1917. When, at last, land was accorded to the indigenous populations in the region in the 1930s, this was mainly the worst plots of land on steep slopes. While ladino ranchers held enormous plots, the indigenous in Los Altos had to be settled in the lowland Lacandón jungle, owing to an explosion of demand for land. ${ }^{107}$ As Nick Henck has convincingly argued, there was no need to cajole the local population into joining an armed uprising, since the campesinos needed urgent protection against the violence of powerful landlords. ${ }^{108}$

According to Tariq Ali, however, the Zapatista philosophy to "change the world without taking power" is nothing but a "moral slogan" that fails to generate concrete gains because it does not threaten patterns of domination. ${ }^{109}$ The Plan Puebla-Panama, likened by a Zapatista farmer to a "cold war [...] a war of low prices, so that we die off," 110 still hovers above the region as a mighty state-backed neoliberal scheme of privatization and exploitation. But considering the sedimentation process, it is a mistake to claim that no concrete gains were made. The idea that there is a lack of contact between labor unions and the Zapatistas, for instance, overlooks the impact that the EZLN had on union leaders. As one study on independent unions in Mexico has revealed, there were encounters between workers and EZLN members. In the words of one unionist,

About a year ago there was a beautiful encounter between the workers and the indigenous of the Zapatista army [...]. From that encounter we have formed really strong bonds between their army and our union, solidarity has even grown from that day. We have sent fellow workers to give the Zapatistas the service of electricity, we do it on our own, we take the cables and the generators and everything they need and leave them there so that they can have electricity. ${ }^{111}$

106 George A. Collier, "Zapatismo Resurgent. Land and Autonomy in Chiapas," NACLA Report on the Americas 33, no. 5 (2000): 20.

107 Ross, Rebellion from the Roots, 69-70.

108 Henck, Subcommander Marcos, 84.

109 Cited by Neil Harvey, "Inclusion through Autonomy: Zapatistas and Dissent," NACLA Report on the Americas 39, no. 2 (2005): 14.

110 Interviewed by Harvey, Ibid.: 15 .

111 Interviewed by Alex Khasnabish, "Moments of Coincidence: Exploring the Intersection of Zapatismo and Independent Labour in Mexico," Critique of Anthropology 24, no. 3 (2004): 266. 
Furthermore, the Zapatista approach to doing politics through grassroots consultations and respect for divergence of opinion has had an effect on decision-making in previously hierarchical organizations. To cite a union leader once again:

We're trying to listen more to each other and that change has not been made from one day to another, it's a process of change. Most of the independent unions, for example, are now fighting for the San Andres Accords as well as for their own needs and demands, so now we share demands. ${ }^{112}$

It is possible to assert that the experience of autonomy has had a considerable impact on the lives of the indigenous population in Zapatista territory in Chiapas. Hospitals and schools have been erected where none were available previously. According to a Zapatista spokesperson at the Third Intergalactic Encuentro in July of 2007, the construction of a school in the Caracol of Oventic provoked the government to build two in nearby villages: "But there are either no teachers in those schools or they are too drunk to teach." The communities choose what they consider important to teach to children (mathematics, indigenous language and culture, history of the community and natural sciences in Roberto Barrios, for example). Nobody fails any class because every student is considered to have his/her own rhythm of learning. The Zapatistas have replaced grading with more communitarian forms of evaluation: "We don't use grades because nobody knows more or less than anybody else." Trainees called promotores have been educated in seminars or workshops to serve in Zapatista clinics and schools. These have not been funded by the Mexican government, but rather by Zaparista solidarity groups in Europe. A much-needed vaccination program is underway. Another problem that the communities have learnt to deal with is the disposal of human waste. Each municipio has commissions for health, education, agriculture, justice and treasury. Locals proudly point to the latrines they have installed in the Caracoles (which served over 2,000 people this summer at Oventic) and reflect upon ways to utilize excrement as fertilizers. Much land has been confiscated from ranchers. A civil registrar's office has also been set up in the communities to register newborn babies, since the government was not doing its job. In short, the communities affirm that they are "learning by doing" (aprendiendo en practicando).

In fact, the need for pooling resources has also given rise to a series of feminist practices: women participate fully in the production and mar- 
keting process and have a say in how the income is spent. They have voiced their concerns over the abuse of alcohol, for instance. Not only were their husbands wasting hard-earned money, but they were also beating their wives when drunk. This is why alcohol is forbidden in Zaparista-controlled territories. The Zapatistas have also promulgated a Revolutionary Women's Law that gives the women the right to choose their partner and decide their number of children. ${ }^{113}$ On another front, on the traditional shirts embroidered and sold by Zapatista women's cooperatives, a label mentions the name of the producer and the hours she spent on the shirt. This is clearly an anti-capitalist practice that significantly reduces what Marx has called "commodity fetishism."

In short, the Zapatista movement has shifted from the spectacular to the everyday. The space it has acquired in the domestic political arena in Mexico certainly does not match its enduring impact on activists elsewhere. But the EZLN was confronted with relative inertia during the Other Campaign, which intended to tour Mexico to unite the oppressed in a nation-wide movement. The Zapatistas have now turned "inward," so to speak, to tend to the realization of autonomy. One commentator sees this as the sign of the Zapatista's failure to adapt: "Radical refusal of any engagement with the neoliberal state gains transformative traction to the extent that it simultaneously articulates, symbolically and in daily political practice, with those who struggle from other sociopolitical locations." ${ }^{14}$ The potential for forging such articulations seems weak indeed, for the Mexican government's full-fledged neoliberal strategy finds little resistance in places other than Chiapas.

\section{In lieu of a conclusion}

Both the Kurdish movement and the Zapatistas are under the assault of the discourse of "necessity"- the discourse of the necessity of privatization, delocalization, commodification, or the discourse of the necessity of national security, personal security, urban security, and so on. Military operations are still an option in southeastern Turkey, while paramilitary operations have heightened in Chiapas. But a more cunning strategy for

113 EZLN, "Revolutionary Women's Law," in The First World, Ha Ha Ha! The Zapatista Challenge, ed. Eliane Katzenberger (San Franscisco: City Lights, 1995). See also Elena Poniatowska, "Women's Battle for Respect: Inch by Inch," in The Zapatista Reader, ed. Tom Hayden (New York: Thunder's Mouth Press/Nation Books, 2002); and R. Aida Hernandez Castillo, "Zapatismo and the Emergence of Indigenous Feminism," in Dispatches from Latin America. On the Frontlines against Neoliberalism, eds. V. Prashad and T. Ballvé (Cambridge: South End Press, 2006).

114 Charles Hale, "Rethinking Indigenous Politics in the Era of the "Indio Permitido," in Dispatches from Latin America. On the Frontlines against Neoliberalism, eds. V. Prashad and T. Ballve (Cambridge: South End Press, 2006), 277. 
subjugating the local population is also taking place through neoliberal agricultural and social policies. NGOs are part and parcel of this process in Turkey. While the Zapatistas have succeeded in establishing control over NGO activity in Chiapas, multinationals are vying over the region to take a hold of natural resources, such as lumber and water.

Without doubt, the Kurdish movement can be said to have altered both Turkish politics and the lives of Kurds in Turkey. If hardliners do not intervene in the present political process, there is a strong likelihood that Kurdish identity will eventually be "normalized." This would probably democratize the legal and cultural structures in the country, replacing former norms and imaginaries with less rigidly defined ones. A domino effect would then be launched whereby orher identities (Armenian, Jewish, Arabic) and beliefs (Alevi, Yezidi) would also be liberated. In this optimistic scenario, Turkey would become a genuine liberal democracy and even be accepted into the EU.

But, even if all this happens, what are the prospects for halting the evacuation of the countryside under the impact of neoliberal reforms? What would be available as a source of income for Kurdish peasants in the Southeast, other than the micro-credit scheme already offered? How would this obstruct the "cleaning up" of neighborhoods adjacent to Diyarbakir's ancient walls with the aim of making the city a tourist attraction? Who would guarantee a decent future to the inhabitants of those neighborhoods, most of them populated by migrants whom the army has driven out of their villages? "Where does Diyarbakır end and where does İstanbul begin?", as one local activist asked. What social mechanism would alter the fate of Kurdish migrants' children who are sent to large cities in western Turkey to collect garbage? As a matter of fact, how would these self-assigned garbage collectors be protected against multinationals that collaborate with municipalities to throw them out of the waste industry, which has revealed itself to be a very lucrative one? Who will represent any of these excluded, marginalized, stigmatized? Through which political channels would they be able to express their voices? Who or what could save them from being rendered invisible via urban planning and other gentrification schemes? And, if no right answer may be found to such questions, will the "Kurdish problem" have been solved?

These and many other questions blur the assessment criteria in such a way as to make one wonder whether any social movement could actually enhance grassroots democracy without having an alternative political and economic vision. The Zapatistas might as well fail to form a nation-wide alliance and suffocate within a physical place. But what 
would then remain is Zapatismo, a philosophy and method of struggle. Such movements as the Zapatistas are

distinguishable in part by their capacity to recognise and act creatively upon connections among structures, processes and peoples that do not enter significantly into the calculations of conventional political actors $[. .$.$] not only in struggles around specific problems but also in$ struggles that recognise the emancipatory potential inherent in certain kinds of connections and solidarities. ${ }^{115}$

Indeed, the space that Zapatismo has opened in imaginaries elsewhere than in Mexico is what made this study possible.

\section{References}

Anonymous author, "The Case of the PKK: History, Ideology, Methodology, and Structure (1978-99)." Ankara Papers 9, no. 1 (2004): 21.59.

Barkey, Henri J. "The People's Democracy Party (HADEP): The Travails of a Legal Kurdish Party in Turkey." Journal of Muslim Minority Affairs 18, no. 1 (1998): 129-138.

Bianet. "Amaç Barışı Kuracak Toplumsal Orgütlenme." (2007), http://www.bianet.org/bianet/insanhaklari/g0221-amac-barisi-kuracak-toplumsal-orgutlenme.

—. "DTP: Ezilenlerin Sesi Olmayı Başaramadık." (2007), http://www.bianet.org/bianet/siyaset/100883dtp-ezilenterin-sesi-olmayi-basaramadik.

Bosco, Fernado J. "Place, Space, Networks and the Sustainability of Collective Action: The Madres de Plaza de Mayo." Clobal Networks 1, no. 4 (2001): 307-329.

Bozarslan, Hamit. "Turkey's Elections and the Kurds." Middle East Report no. 199 (1996): 16-19.

Castillo, R. Aida Hernandez. "Zapatismo and the Emergence of Indigenous Feminism." In Dispatches from Latin America. On the Frontlines against Neoliberalism, edited by V. Prashad and T. Ballve, 229-242. Cambridge: South End Press, 2006.

Cemal, Hasan. "Basın General Emri Dinlememeli (Interview with Neşe Düzel)." Radikal, 26 May 2003.

Collier, George A. "Zapatismo Resurgent. Land and Autonomy in Chiapas." NACLA Report on the Americas 33. no. 5 (200o): 20-23.

Couch, Jen. "Imagining Zapatismo: The Anti-Globalisation Movement and the Zapatistas." Communal/ Plural 9, no. 2 (2001): 243-260.

"DEHAP Çözüm Arayışında." Radikal, 21 April 2005.

"DTP Güneydoğu'da Ezdi Geçti." Radikal, 30 March 2009.

"DTP’li Türk: Kürtler 4 Bin Yıldır Bu Topraklarda, Azınlık Değildir." Radikal, 9 January 2008.

Diken, Şeyhmus. Güneydoğ'da Sivil Hayat. Istanbul: Metis, 2001.

Edelman, Marc. "Social Movements: Changing Paradigms and Forms of Politics." Annual Review of Anthropology no. 30 (2001): 285-317.

Eder, Klaus. "The New Social Movements: Moral Crusades, Political Pressure Croups, or Social Movements." Social Research 52, no. 4 (1985): 869-90.

Escobar, Arturo. "Culture Sits in Places: Reflections on Globalism and Subaltern Strategies of Localization." Political Ceography 20, no. 2 (2001): 139-174.

EZLN. "Communiqué Regarding Elections." (2000), http://flag.blackened.net/revolt/mexico/ezln/2000/ ccri_elections_june.html.

115 Rob B. Walker, One World, Many Worlds: Struggles for a Just World Peace, Explorations in Peace and Justice (Boulder, Colo.: Lynne Rienner, 1988), cited in Watson, "An Examination of the EZLN," 71. 
"Revolutionary Women's Law." In The First World, Ha Ha Ha! The Zapatista Challenge, edited by Eliane Katzenberger, 109-110. San Franscisco: City Lights, 1995.

Friedman, Debra, and Doug McAdam. "Collective Identity and Activism: Networks, Choices, and the Life of a Social Movement." In Frontiers in Social Movement Theory, 156-173.

Cambetti, Zeynep. "Conflict, 'commun-ication' and the Role of Collective Action in the Formation of Public Spheres." In Publics, Politics and Participation: Locating the Public Sphere in the Middle East and North Africa, edited by Seteney Shami. New York: Columbia/SSRC Books, 2010 [forthcoming].

-. "The Conflictual (Trans)formation of the Public Sphere in Urban Space: The Case of Diyarbakir." New Perspectives on Turkey no. 32 (2005): 43-71.

- "Decolonizing Diyarbakır: Culture, Identity and the Struggle to Appropriate Urban Space." In Comparing Cities: The Middle East and South Asia, edited by Kamran Asdar Ali and Martina Rieker, 95. 127. Karachi: Oxford University Press, 2009.

—. "Linç Girişimleri, Neo-Liberalizm ve Güvenlik Devleti." Toplum ve Bilim no. 109 (2007): 7-34.

Garcia de Leon, Antonio. "Chiapas and the Inverting of Established Orders." Identities 3, no. 1-2 (1996): $261-268$.

Gieryn, Thomas F. "A Space for Place in Sociology." Annual Review of Sociology no, 26 (2000): 463-496.

Goodwin, Jeff, and James M. Jasper. "Caught in a Winding, Snarling Vine." In Rethinking Social Movements: Structure, Meaning, and Emotion, edited by Jeff Goodwin and James M. Jasper. Lanham: Rowman and Littlefield Publishers, 2004.

Habermas, Jürgen. "New Social Movements." Telos no. 49 (1981): 33-37.

-. The Theory of Communicative Action, Vol. 2, System and Lifeworld: A Critique of Functionalist Reason. Cambridge: Polity Press, 1987.

Hale, Charles. "Rethinking Indigenous Politics in the Era of the 'Indio Permitido'." In Dispatches from Latin America. On the Frontlines against Neoliberalism, edited by V. Prashad and T. Ballvé, 266-280. Cambridge: South End Press, 2006.

Harvey, David. The Condition of Postmodernity. Oxford: Basil Blackwell, 1989.

—. "Neoliberalism as Creative Destruction." Geografiska Annaler 88B, no. 2 (2006): 145-58.

- Spaces of Hope. Berkeley: University of California Press, 2000.

Harvey, Neil. "Inclusion through Autonomy: Zapatistas and Dissent." NACLA Report on the Americas 39, no. 2 (2005): 12-17.

Hassanpour, Amir. "The Creation of Kurdish Media Culture." In Kurdish Culture and Identity, edited by P. G. Kreyenbroek and C. Allison, 48-84. London and New Jersey: Zed Books, 1996.

Henck, Nick. Subcommander Marcos: The Man and the Mask. Durham and London: Duke University Press, 2007.

Higgins, Nicholas P. "Mexico's Stalled Peace Process: Prospects and Challenges." International Affairs 77, no. 4 (2001): 885-903.

Jenkins, J. Craig. "Resource Mobilization Theory and the Study of Social Movements." Annual Review of Sociology no. 9 (1983): 527-53.

Khasnabish, Alex. "Moments of Coincidence: Exploring the Intersection of Zapatismo and Independent Labour in Mexico." Critique of Anthropology 24, no. 3 (2004): 256-276.

Kurban, Dilek, Deniz Yükseker, Ayşe Betül Çelik, Turgay Ünalan, and A. Tamer Aker. Coming to Terms with Forced Migration: Post-Displacement Restitution of Citizenship Rights in Turkey. İstanbul: TESEV, 2007.

Kutschera, Chris. "Disarray inside PKK." The Middle East, May 2000, 18.

Küçüközer, Mehmet. "Peasant Rebellion in the Age of Clobalization: The Zapatistas of Mexico and the Kurds of Turkey." Ongoing Ph.D. diss., City University of New York.

Lefebvre, Henri. The Production of Space. Oxford, UK and Cambridge, Mass.: Blackwell, 1991.

Massey, Doreen. Spatial Divisions of Labor: Social Structures and the Geography of Production. revised $2^{\text {nd }}$ ed. New York: Routledge, 1995.

McAdam, Doug. Political Process and the Development of Black Insurgency, 1930-1970. $2^{\text {nd }}$ ed. Chicago: University of Chicago Press, 1999.

McAdam, Doug, John McCarthy, and Mayer N. Zald. "Introduction: Opportunities, Mobilizing Structures, and Framing Processes - toward a Synthetic, Comparative Perspective on Social Movements." In Comparative Perspectives on Social Movements: Political Opportunities, Mobilizing Structures and Cultural Framings, edited by Doug MCAdam, John McCarthy and Mayer N. Zald, 1-20. Cambridge: Cambridge University Press, 1996. 
McCarthy, James, and Mayer N. Zald. "Resource Mobilization and Social Movements." American Journal of Sociology 82, no. 6 (1977): 1212.41.

Medyaname. "KCK Yürütme Konseyi Üyesi Duran Kalkan PKK Bundan Sonra Ne Yapacak Sorusunu Yanıtladı." (2007), http://www.medyaname.com/tr/index.php?option=pek_content\&task=view\&id= $1049 \&$ Itemid=1689 (accessed September 5, 2008).

Melucci, Alberto. "The Symbolic Challenge of Contemporary Movements." Social Research 52, no. 4 (1985): $789-816$.

Miller, Byron. Geography and Social Movements. Minnesota: University of Minnesota Press, 2000.

Morris, A. D., and C. M. Mueller, eds. Frontiers in Social Movement Theory. New Haven and London: Yale University Press, 1992.

Nelson, Lise. "Decentering the Movement: Collective Action, Place, and the 'Sedimentation' of Radical Political Discourses." Environment and Planning D: Society and Space 21, no. 5 (2003): 559-582.

Oktem, Kerem. "Incorporating the Time and Space of the Ethnic 'Other': Nationalism and Space in Southeast Turkey in the Nineteenth and Twentieth Centuries." Nations and Nationalism 10, no. 4 (2004): 559-578.

Özcan, Ali Kemal. "The Vacillating PKK: Can It Be Resurrected?" Middle Eastern Studies 43, no. I (2007): 107-124.

Paz, Maria Fernando. "Searching for Root Causes: A Historical Background Sketch of the Protagonists of the Zapatista Uprising." Identities 3, no. 1-2 (1996): 235-252.

Polletta, Francesca. "'Free Spaces' in Collective Action." Theory and Society 28, no. 1 (1999): 1-38.

Poniatowska, Elena. "Women's Battle for Respect: Inch by Inch." In The Zapatista Reader, edited by Tom Hayden, 55-57. New York: Thunder's Mouth Press/Nation Books, 2002.

"Sakık: PKK Bu Ülkenin Gerçeği ve Meclis'te de Konuşulmalı," Radikal, 6 December 2007.

Ramirez, Gloria Munoz. Ateş ve Söz. 20. ve 10. Yılında EZLN. İstanbul: Ayrıntı, 2005.

-... "Chiapas, La Résistance." Réseau d'information et de solidarity avec l'Amerique Latine, (2004), http:// risal.collectifs.net/article.php3?id_article $=1194$.

Ross, John. Rebellion from the Roots: Indian Uprising in Chiapas. Monroe, Main: Common Courage Press, 1995 .

Sewell, William. "Space in Contentious Politics." In Silence and Voice in the Study of Contentious Politics, edited by Ronald Aminzade et al., 51-88. Cambridge: Cambridge University Press, 2001.

Smith, Neil. "Contours of a Spatialized Politics: Homeless Vehicles and the Production of Ceographical Scale." Social Text no. 33 (1992): 55-81.

- Uneven Development: Nature, Capital, and the Production of Scale. $3^{\text {rd }}$ ed. Athens: University of Georgia Press, 2008.

Soja, Edward. Postmetropolis: Critical Studies of Cities and Regions. Oxford: Blackwell, 2000.

-. Postmodern Geographies: The Reassertion of Space in Critical Social Theory. London: Verso, 1989.

Stahler-Sholk, Richard. "Autonomy and Resistance in Chiapas." In Dispatches from Latin America: On the Frontlines against Neoliberalism, edited by V. Prashad and T. Ballve, 215-228. Cambridge: South End Press, 2006.

-.. "Globalization and Social Movement Resistance: The Zapatista Rebellion in Chiapas, Mexico." New Political Science 23. no. 4 (2001): 493-516.

Subcommandante Marcos. Our Word Is Our Weapon. Selected Writings, edited by J. Poncé de Leon. New York: Seven Stories Press, 2002.

Taminiaux, Jacques. La fille de Thrace et le penseur professionnel: Arendt et Heidegger. Paris: Payot, 1992.

Tarrow, Sidney. Democracy and Disorder. Oxford: Oxford University Press, 1989.

—. Power in Movement. Cambridge: Cambridge University Press, 1998.

- "Silence and Voice in the Study of Contentious Politics: Introduction." In Silence and Voice in the Study of Contentious Politics, edited by Ronald Aminzade et al., 1-13. Cambridge: Cambridge University Press, 2001.

Tilly, Charles. "Contentious Repertoires in Great Britain, 1758-1834." In Repertoires and Cycles of Contention, edited by M. Traugott, 15-42. Durham: Duke University Press, 1995.

- From Mobilization to Revolution. Reading: Addison-Wesley, 1978.

Touraine, Alain. "An Introduction to the Study of Social Movements." Socinl Research 52, no. 4 (1985): 749-787.

Walker, Rob B. One World, Many Worlds: Struggles for a Just World Peace, Explorations in Peace and Justice. 
Boulder, Colo.: Lynne Rienner, 1988.

Wallerstein, Immanuel. "The Zapatistas: The Second Stage." Commentary no. 165, 15 July 2005, http://fbc. binghamton.edu/165en.htm.

Watson, lain. "An Examination of the Zapatista Army of National Liberation (EZLN) and New Political Participation." Democracy and Nature 8, no. 1 (2002): 63-86.

Wilton, Robert D., and Cynthia Cranford. "Toward an Understanding of the Spatiality of Social Movements: Labor Organizing at a Private University in Los Angeles." Social Problems 49, no. 3 (2002): 374-394. Yeğen, Mesut. Müstakbel Türk'ten Sözde Vatandaşa. Istanbul: Metis, 2006. 